\title{
Integration of HVSR measures and stratigraphic constraints for seismic microzonation studies: the case of Oliveri (ME)
}

P. Di Stefano, D. Luzio, P. Renda, R. Martorana, P. Capizzi, A. D’Alessandro, N. Messina, G. Napoli, S. Todaro, and G. Zarcone

Dipartimento di Scienze della Terra e del Mare - DiSTeM, University of Palermo, Italy Received: 6 March 2014 - Accepted: 1 April 2014 - Published: 10 April 2014

Correspondence to: R. Martorana (raffaele.martorana@unipa.it)

Published by Copernicus Publications on behalf of the European Geosciences Union.

Integration of HVSR measures and stratigraphic constraints

P. Di Stefano et al.

\section{Title Page}

Abstract

Introduction

Conclusions

References

Tables Figures

14 I

4

Back

Close

Full Screen / Esc

Printer-friendly Version

Interactive Discussion 


\section{Abstract}

Because of its high seismic hazard the urban area of Oliveri has been subject of first level seismic microzonation. The town develops on a large coastal plain made of mixed fluvial/marine sediments, overlapping a complexly deformed substrate. In order to iden5 tify points on the area probably suffering relevant site effects and define a preliminary $V_{s}$ subsurface model for the first level of microzonation, we performed 23 HVSR measurements. A clustering technique of continuous signals has been used to optimize the calculation of the HVSR curves. 42 reliable peaks of the $H / V$ spectra in the frequency range $0.6-10 \mathrm{~Hz}$ have been identified. A second clustering technique has been applied to the set of 42 vectors, containing Cartesian coordinates, central frequency and amplitude of each peak to identify subsets which can be attributed to continuous spatial phenomena. The algorithm has identified three main clusters that cover significant parts of the territory of Oliveri. The HVSR data inversion has been constrained by stratigraphic data of a borehole. To map the trend of the roof of the seismic bedrock, from the complete set of model parameters only the depth of the seismic interface that generates peaks fitting those belonging to two clusters characterized by lower frequency has been extracted.

The reconstructed trend of the top of the seismic bedrock highlight its deepening below the mouth of the Elicona Torrent, thus suggesting the possible presence of a buried paleo-valley.

\section{Introduction}

The dynamic characteristics of a seismic phase of body or surface waves, generated by an earthquake and incident on a portion of the ground surface, often show sharp variations, frequency dependent, sometimes having extremely local character.

A very minor heterogeneity of the same parameters, in large part explained by differences between the ray paths from the source to the observation points and by the
NHESSD

2, 2597-2637, 2014

\section{Integration of HVSR measures and stratigraphic constraints \\ P. Di Stefano et al.}

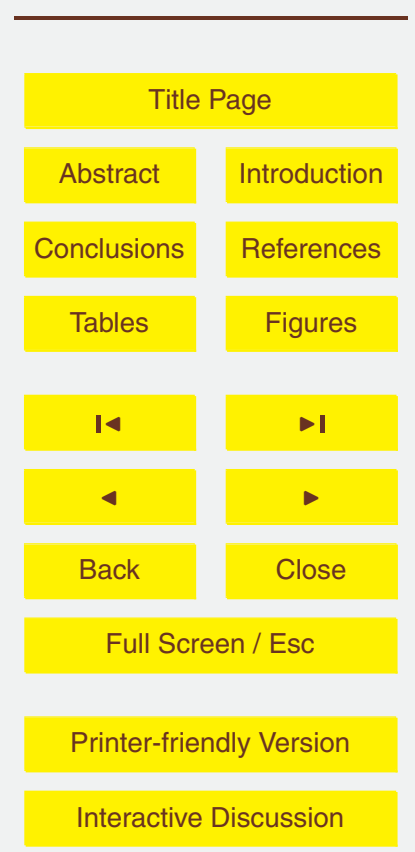


source model, has often been observed in extensive sub-planar outcrops of rocks characterized by high body wave velocity and high layer thickness. These conditions are commonly approximated by the requirement that the velocity of shear waves is greater than $800 \mathrm{~ms}^{-1}$. A layer with these characteristics, generally not outcropping, is called 5 seismic bedrock.

There can be many causes for the sharp spatial variation of the transfer function between the roof of the bedrock and the surface of the soil as e.g.: resonance in soils, multiple reflection, constructive interference and focusing geometry for topographic and buried interface irregularities.

10 Significant increases in amplitude of the phases for which occur peak values of the kinematic parameters of ground shaking, which may be the cause of relevant coseismic effects (fractures, landslides, liquefaction, ....) for buildings and infrastructure, are called site effects. In general all this phenomena are controlled by anomalies in the mechanical properties of the shallowest layers of subsoil, when it consists of soft sediments, or by the shape of surfaces of discontinuity close to or coincident with the topographic surface.

If we knew a very detailed mechanical model of the cover layer, consisting of soft sediment, assuming that the layer behaves with respect to the propagation of waves in an approximately linear way, we could predict the site effects or even determine univocally its transfer function by means of numerical calculation.

The difficulty and costliness of the reconstruction of a suitable model of subsurface using geophysical techniques and the necessity of not neglecting nonlinear effects as: deamplification of strong motion and increase of the effective resonance period of soil deposits as the level of excitation increases (Dimitriu et al., 2000) has led many researchers to develop and adopt more direct techniques that allow to determine approximated empirical transfer functions.

Everywhere on the Earth's surface a seismic station may record ground vibrations produced by interference of body and surface waves, generated by sources randomly distributed in the subsoil and known as seismic noise or microtremors.
NHESSD

2, 2597-2637, 2014

Integration of HVSR measures and stratigraphic constraints

P. Di Stefano et al.

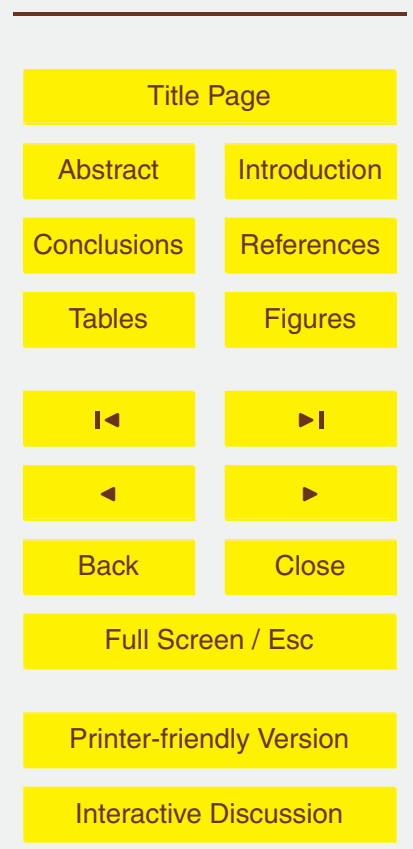


Nakamura (1989) proposed a technique based on the calculation of the ratio of the power spectra of the horizontal and vertical components of the seismic noise recorded a single three components seismic station. The power spectra of the horizontal and vertical components of the seismic noise are everywhere affected by characteristics of 5 the sources, as well as by the distribution of the mechanical parameters in the subsoil. Nakamura (1989) showed that in correspondence to the resonance frequencies of a sequence of layers, the Horizontal to Vertical Spectral Ratio (HVSR) of the seismic noise presents peaks well correlated with the amplification factor of $S$ waves, generated by earthquakes, between the bottom and the roof of the stratification. Not necessarily, 10 however, an HVSR peak must be attributed to resonance frequencies of a buried structure, it might also depend on characteristics of the sources of noise and in such case will not be correlated with amplification effects on incident waves trains. However, appropriate techniques of data analysis may help to discriminate, between peaks caused by source effects and those due to wave propagation.

15 The main sources of seismic noise are: atmospheric and hydrodynamic phenomena, and fluid circulation and micro-fracturing processes in the subsoil. Close to residential areas, anthropogenic sources produce seismic noise, mainly with a relatively high average frequency, compared to the natural noise (typically higher than $10 \mathrm{~Hz}$ ).

Assuming a simple composition of the noise in terms of body and surface waves,

having an adequate information on th of constraints for a one-dimensional model of the subsoil, it is possible to determine the unknown parameters of the model by inversion of the curves HVSR.

The seismic microzonation of a territory aims to recognize the small scale geological and geomorphological conditions that may significantly affect the characteristics of the seismic motion, generating high stress on structures that could produce permanent and critical effects (site effects) (Ben-Menahem and Singh, 1981; Yuncha and Luzon, 2000). The first phase of the seismic micro-zoning is the detailed partition of the territory in homogeneous areas with respect to the expected ground shaking during an earthquake.
NHESSD

2, 2597-2637, 2014

Integration of HVSR measures and stratigraphic constraints

P. Di Stefano et al.

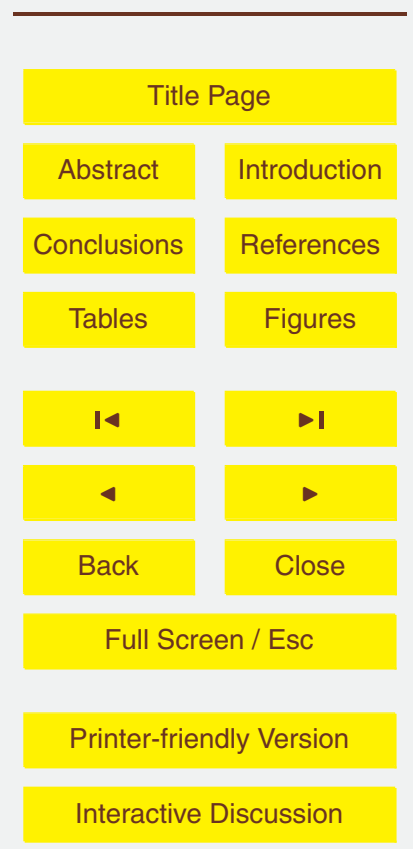


This paper focus on a recent micro-zoning study of the Oliveri urban area, a village settled on a coastal plain in Northeastern Sicily.

This area is among those with highest seismic hazard, selected for the first year of the project Studies of Seismic Micro-zoning, established by the Prime Minister's Order 5 no. 3907.

Taking into account that a geological feature of this area is a thick blanket of coastal deposits that cover the substrate seismic, in this paper we focused only on the reconstruction of the thickness of the sedimentary cover and its effect on the site response. The experimental data that have been collected are derived from: a geological survey, 10 an inventory of existing wells and a geophysical survey, carried out using the technique HVSR.

\section{Seismotectonic setting}

The area of Oliveri is part of the Peloritani Mountains, a segment of the Maghrebian chain that is mainly constituted by a pile of tectonic units consisting of Hercynian metamorphic rocks and their Meso-Cenozoic sedimentary covers.

According to Giunta et al. (1998), the tectonic pile of the Peloritani Mountains is formed by the following units:

- Longi-Taormina Unit, made of an epimetamorphic basement covered by a MesoCenozoic sedimentary sequence;
- Fondachelli Unit, consisting of phyllites and rare metarenites, metabasites and meta-limestones;

- Mandanici Unit, consisting of phyllites, quartzites, metabasites, marbles and porfiroids;

- Mela Unit, characterized by a polimetamorphic basement, represented by paragneiss and micaschists, with intercalations of metabasites and marbles;
NHESSD

2, 2597-2637, 2014

Integration of HVSR measures and stratigraphic constraints

P. Di Stefano et al.

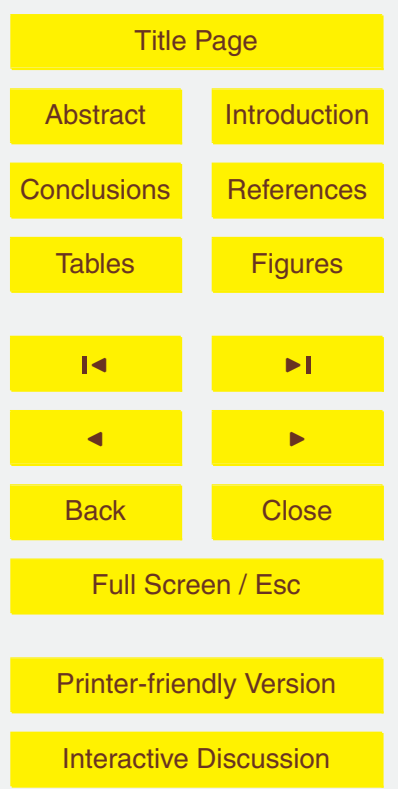


- Aspromonte Unit, consisting of a medium-high degree metamorphic basement, with paragneiss and micaschists, gneiss, metagranits, amphibolites, and marbles.

These units are overlapped by Oligo-Miocene siliciclastic turbidites pertaining to the Stilo-Capo d'Orlando Formation.

5 Upward follow, through a tectonic contact, the Antisicilide Units (Ogniben, 1970), which are represented by the Argille Variegate, that are in turn unconformably overlain by the Miocene Floresta Calcarenites (Ogniben, 1960, 1969; Guerrera e Wezel, 1974). Plio-Pleistocene calcarenites and clays are preserved in tectonic depression.

In the Peloritani Mountains different deformation steps that are related to the Alpine orogeny, are superimposed to the Hercynian ductile deformations. The Oligo-Miocene contraction has been characterized by several phases in which there has been the formation of folds associated with thrust systems that have fragmented and stacked the crystalline rocks and their sedimentary covers in different tectonic units.

Reverse fault systems (breaching) affected the area since the Upper Miocene resulting in moderate shortening (Giunta and Nigro, 1998). At the end of the Miocene the Tyrrhenian rifting produced a series of extensional low angle faults that resulted in a thinning of the chain. During Plio-Pleistocene times the area occupied by the Peloritani Mountains was affected by a strike-slip tectonic phase that generated two different systems: the first one synthetic with right cinematic and oriented NW-SE and E-W; the second one antithetical, mainly sinistral and oriented N-S and NE-SW (Ghisetti and Vezzani, 1977, 1984; Ghisetti, 1979; Boccaletti et al., 1986; Finetti and Del Ben, 1986; Malinverno and Ryan, 1986; Giunta, 1991; Mauz and Renda, 1995; Nigro and Sulli, 1995; Abate et al., 1998; Nigro, 1998; Nigro and Renda, 1999, 2000, 2002, 2005).

The deformations are still actives and result in thrusts, within the chain, and crustal 25 thinning in the Tyrrhenian area (Finetti, 1982; Finetti et al., 1996; Giunta et al., 2000). The geometry of thrusts are ramp-flat-ramp like (Nigro, 1994; Giunta and Nigro, 1998) or in some cases are the result of duplex structures (Nigro,1994; Giunta and Somma, 1996).
NHESSD

2, 2597-2637, 2014

Integration of HVSR measures and stratigraphic constraints

P. Di Stefano et al.

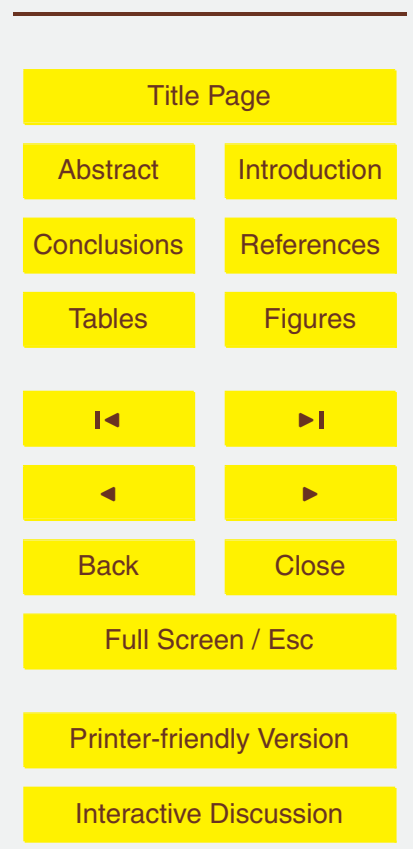


Around the Oliveri's plain there is evidence of active tectonics due to a right-lateral shear zone named Aeolian-Tindari-Letojanni fault (Ghisetti, 1979; Ghisetti and Vezzani, 1979). This fault is generated by two different geodynamic domains: compressive to west, related to a roughly $\mathrm{N}-\mathrm{S}$ trusting produced by continental collision, and exten5 sional to east, controlled by NW-SE expansion of the Calabro-Peloritan Arc (De Guidi et al., 2013). The analysis of seismic and geodetic data, acquired in the last 15 years, and structural and morphological surveys show evidence of tectonic activity in this area as recent as the middle-upper Pleistocene (Catalano and Di Stefano, 1997; Ghisetti, 1979; De Guidi et al., 2013). Recent studies, not far from the Oliveri's plain, have char10 acterized some geothermal springs and gas vents and discussed their possible role in the generation of earthquakes (Giammanco et al., 2008) and a very high rate of uplift (up to $5.5 \mathrm{~mm}$ year $^{-1}$ ) has been estimated on the base of paleontological data (Di Stefano et al., 2012).

The morphological features of Oliveri town are represented mainly by an alluvial 15 plain, where lies the town itself, and by a hilly landscape that surrounds the southern and western part of the plain. Both the hills and the plain are crossed by the Torrente Castello and Torrente Elicona rivers valleys, that are partly filled by silty-sandy and pebbly sediments.

The lithostratigraphic framework of the substrate of the urban area (Fig. 1) is made up by the metamorphic basement of the Aspromonte Unit that is covered unconformably by the arenaceus member of the Capo D'Orlando Flysch. Upwards the flyschoid sediments are tectonically overlain by the Argille Scagliose belonging to the Antisicilide Unit. The previous deposits are capped by sands and calcarenites of Plio-Pleistocene age. The most recent sediments consist of alluvial and beach deposits.

The Oliveri territory is located in the area 932 of the ZS9 seismogenic zonation of Italy (Meletti and Valensise, 2004). It includes seismogenic structures largely known through geophysical exploration. The faults in this area partly allow the retreat of the Calabrian Arc and some are synthetic faults that segment the Gulf of Patti. The area 932 is one of the areas with the highest seismic potential of the whole Sicily. In it
NHESSD

2, 2597-2637, 2014

\section{Integration of HVSR measures and stratigraphic constraints \\ P. Di Stefano et al.}

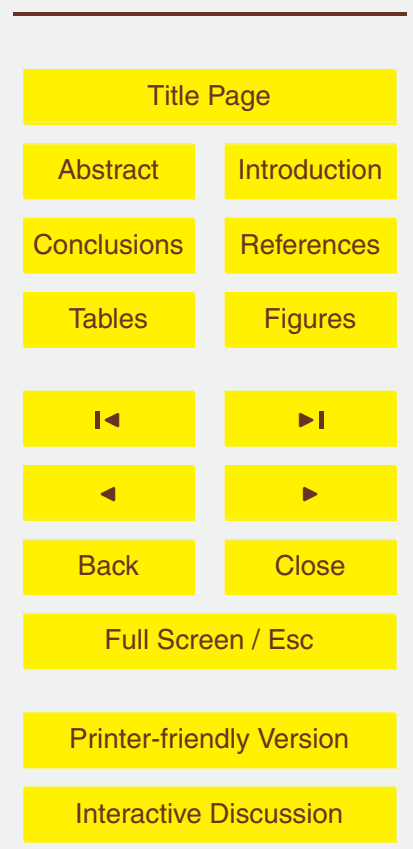


occurred the earthquake of 1908 , for which different source mechanisms have been proposed, some of which are, probably, associated with the activation of complex fault systems or blind faults (Ghisetti, 1992; Valensise and Pantosti, 1992; Monaco and Tortorici, 1995).

5 The high rate of seismicity in the Gulf of Patti and in the area between Alicudi and Vulcano is associated to the two right-slip fault systems, Patti-Volcano-Salina and Sisyphus, respectively oriented NW-SE and WNW-ESE. The most energetic instrumental earthquakes have occurred in this area 15 April 1978 and 28 May 1980 with a local magnitude of 5.5 and 5.7 respectively.

10 The earthquake of $1978\left(M_{\mathrm{W}}=6.6\right)$, related to movements along these faults (Neri et al., 1996), caused considerable damage in many countries of the Messina province and was felt up to the Cosenza province in the north, to Dubrovnik in the south, to Trapani to the west and to the lonian coast of Calabria to the east. The estimated maximum macroseismic intensity has been VIII-IX MCS. Its mean macroseismic intensity 15 in the Oliveri area was VII MCS, where it caused serious damage in some buildings and significant soil fractures (Barbano et al., 1979).

The earthquakes of Novara di Sicilia, with lower magnitude and shallower hypocenters, seem to be linked to structures other than the fault system Patti-Volcano-Salina. The earthquakes of Naso might instead be associated with NE-SW normal faults responsible for the lifting of the chain. Among the structures present in the southern Tyrrhenian sea, those oriented around EO, would be responsible for the events of the western sector of the Aeolian Islands, and may have generated earthquakes like the one in 1823.

Neri et al. (2003) have determined the focal mechanisms of earthquakes with depths less than $50 \mathrm{~km}$, occurred in Calabria and Sicily between 1978 and 2001 . These indicate a high heterogeneity of the deformation field in the area 932 . Here the deformation style ranges from extensional with southwest exposure to compressional with northeast exposure, proceeding from SE to NW.
NHESSD

2, 2597-2637, 2014

Integration of HVSR measures and stratigraphic constraints

P. Di Stefano et al.

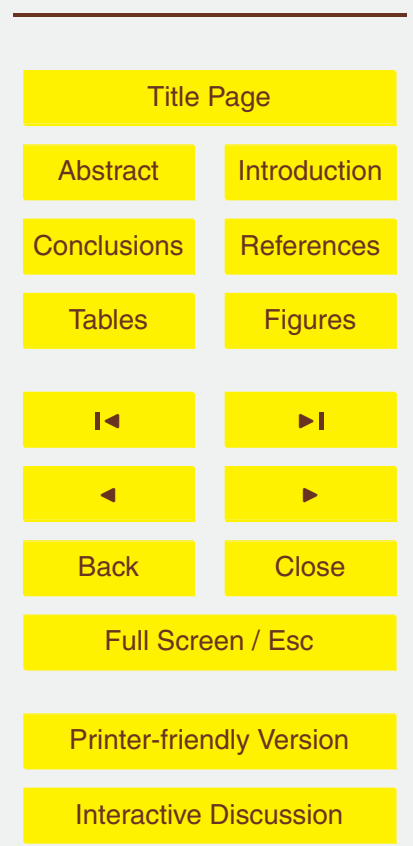


The first earthquake whit a destructive effect in the Oliveri area, reported in the catalogs of historical Italian seismicity, occurred in 10 March 1786. This seismic event was characterized by $M_{\mathrm{W}}=6.15$, epicenter at Oliveri and MCS intensity equal to IX in the urban area. This earthquake severely damaged all the cities of the Gulf of Patti in 5 northern Sicily and almost destroyed the town of Oliveri (Guidoboni et al., 2007).

The seismic activity recorded in the last 20 years the area surrounding the urban center of Oliveri represented in Fig. 2 is characterized by about 3500 events with local magnitude greater than 2 . Of these about $89 \%$ have hypocenters tightly concentrated around an average depth of about $10 \mathrm{~km}$. The remaining $11 \%$ consists of events whose 10 hypocenters are thickened around a plane that dips toward the northwest at an angle of about $60^{\circ}$ and are distributed rather uniformly with respect to depths up to $400 \mathrm{~km}$. The sources of these events are located inside the lonian lithospheric slab that dips under the Calabrian Arc (Giunta et al., 2004).

An analysis of completeness of these data sets has indicated a local magnitude 15 threshold equal to about 2.6.

The shallow seismic activity has a marked tendency to occur through sequences of aftershocks sometimes preceded by foreshocks. This tendency was assessed in a quantitative way by comparing the estimates of the correlation dimension in the domains of the epicenter coordinates and time, both for the component of the seismicity constituted by events not followed by aftershocks and the main shock of the sequences that for the total set of events (Adelfio et al., 2006). The estimates of the space and time correlation dimension relating to independent events are close to those expected for uniform distributions, as opposed to those for the total set that are much smaller.

The geometric characteristics of the clusters related to the shallower seismicity iden25 tify orientations that are consistent with those of the main tectonic structures of the area.

The seismicity of the last 20 years has also been analyzed in the magnitude domain. For the events of the area of Fig. 2 have been estimated the value of $b$ of the law of Gutenberg-Richter and the $95 \%$ confidence interval, using the estimator of Tinti and
NHESSD

2, 2597-2637, 2014

Integration of HVSR measures and stratigraphic constraints

P. Di Stefano et al.

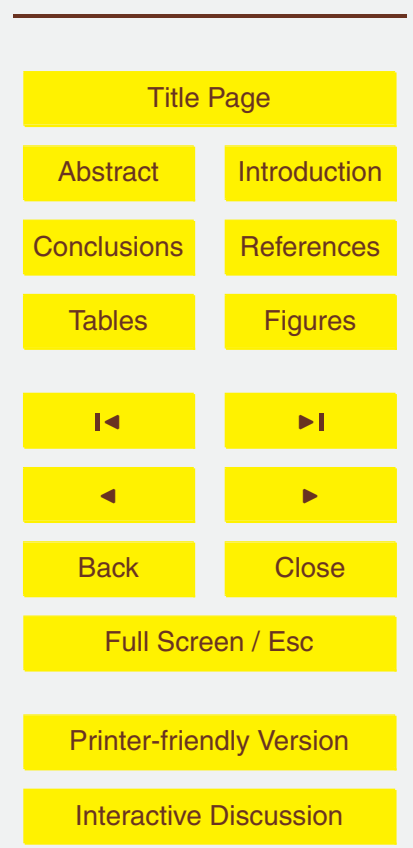


Mulargia (1987) not distorted by the data grouping. In particular, for deeper events, associated with the Ionian slab, the value of $b$ is equal to $0.6 \pm 0.2$ while for superficial events has been estimated the value $1.15 \pm 0.13$ which is comparable with the value obtained for the independent component of the seismicity of the whole south-Tyrrhenian 5 area (see Adelfio et al., 2006).

\section{HVSR measurements and processing}

The HVSR technique, is today one of the most commonly applied methods of expedite microzonation studies of urban areas.

Some open questions and doubts remain, however, on the reliability of HVSR technique, mainly related to the numerous assumptions about: spatial distribution of the microtremor sources, composition of the seismic noise in terms of body, Rayleigh and Love waves and characterization of the propagation medium, often hard to verify.

In fact, if the shape of the HVSR curves is mainly controlled by the $S$ wave transfer function within the shallowest sedimentary layers (Nakamura, 1989, 2000; Parolai 15 et al., 2000; Mucciarelli et al., 2003), both $H / V$ peak frequency and amplitude may be, respectively, related to subsoil resonance frequency and site amplification factor. On the other hand, if the shape of the $H / V$ curves is mainly controlled by the polarization of the fundamental mode of the Rayleigh waves (ellipticity) (Lachet and Bard, 1994; Kudo, 1995; Bard, 1999; Konno and Ohmachi, 1998; Fäh et al., 2001), only an indirect correlation between the $H / V$ peak amplitude and the site amplification can be expected.

Because of the above conceptual difficulties in the assessing of these techniques, many experimental works have played an important role. In these were crosswise analyzed correlations between: peaks of the spectral ratio $H / V$, transfer functions derived by the method SSR (Borcherdt, 1970) and site effects expressed in terms of increases of macroseismic intensity or peak values of the usual ground motion pa-
NHESSD

2, 2597-2637, 2014

Integration of HVSR measures and stratigraphic constraints

P. Di Stefano et al.

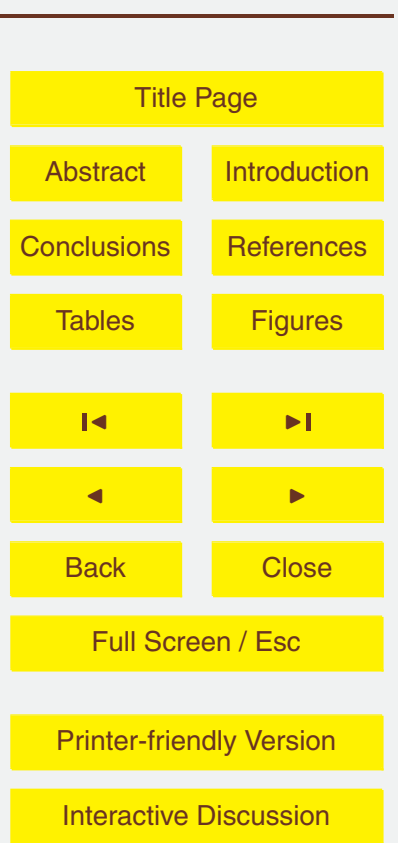


rameters (Dimitriu et al., 2000; Rodriguez et al., 2000; Mucciarelli and Gallipoli, 2004; Panou et al., 2005; De Rubeis et al., 2011).

The results of these analyzes indicate that there is a high spatial correlation between areas in which there are site effects and areas in which the spectral ratios are charac5 terized by peaks of significant amplitude, also highlight the correlation between some of the frequencies of the peaks of the HVSR curves and the main eigenfrequencies of the subsurface structures. A very minor correlation is observed, instead, between the amplitudes of the peaks relating to the different survey techniques and between these and the local amplification of the macroseismic intensity or peak values of the shaking 10 parameters.

In most of the studies reported in the literature this technique has been used to study site effects in sedimentary basins, near faults or cavities or to estimate the resonance frequency of building (e.g. Field and Jacob, 1993; Lermo and Chávez-García, 1994; Mucciarelli, 1998; Bard, 1999; Fäh et al., 2001). In some recent studies some authors (Fäh et al., 2003; Scherbaum et al., 2003; Arai and Tokimatsu, 2004; Parolai et al., 2005, 2006; Picozzi et al., 2005) perform joint and/or constrained inversion of the HVSR curves with information relating to neighboring perforations and other types of geophysical survey, to obtain $S$ waves velocity models.

The foregoing highlights the importance of improving the processing techniques of the recorded signals to be able to link, more reliably, the results of HVSR investigations with site effects.

For this reason an issue to be addressed is related to the processing procedure for the determination of the spectral ratio. In particular, in order to obtain reliable HVSR curves, several criteria must be respected for: acquisition of 3-components signals, selection of the time windows to be used in the SR calculation, computation of the amplitude spectrum for each time window, composition of the amplitude spectra relative to the horizontal components, computation of the HVSR for each window and, finally, computation of the average HVSR (SESAME Project 2004).
NHESSD

2, 2597-2637, 2014

Integration of HVSR measures and stratigraphic constraints

P. Di Stefano et al.

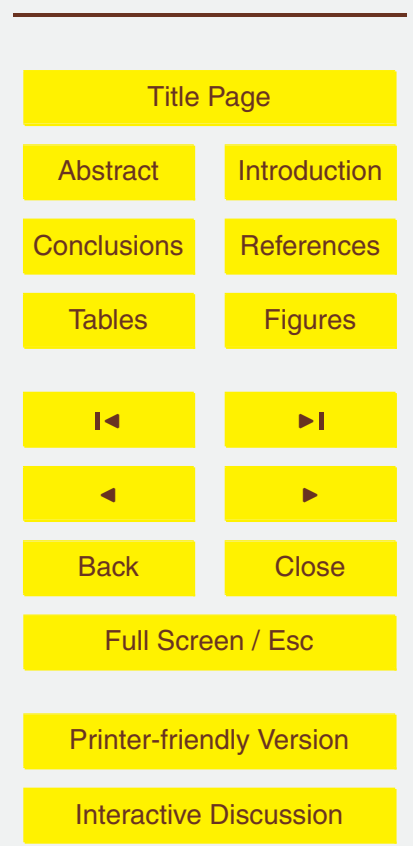


One of the most controversial aspects in the application of the HVSR technique concerns the criteria for the selection, in the microtremor signals, of time windows appropriate for the calculation of the HVSR curves. Several authors assume that spikes and transients, common in all the records, bring information highly dependent from the 5 source and cannot be used to estimate the resonance frequency of the site (Horike et al., 2001). For this reason many authors exclude the non-stationary portion of the recorded noise for the computation of the average HVSR curve, thus considering only the low-amplitude part of signal. Some authors instead (Mucciarelli and Gallipoli, 2004) observed by correlation studies, that the non-stationary, high-amplitude noise windows 10 improves the capability of the HVSR curve to mimic the HVESR curves, obtained with recordings of vibrations induced by weak earthquakes and, therefore, suggest that they should not be removed.

The windows selection can be made scanning in time domain the three components noise signal, or observing the whole set of HVSR curves, related to single time win15 dows, as function of time.

In both cases, while there are in the literature numerous suggestions and prescriptions about this stage of the processing (SESAME Project 2004), the selection of the windows to be used in the calculation of the HVSR curve is highly subjective.

The lack of objective selection criteria leads to several drawbacks. In particular, in20 creasing of the processing duration of the; producing results whose reliability depends on the skill of the operator. The permanence of abnormal windows can cause bias of the estimates of the expected value and the dispersion of the set of selected curves can lead to overestimates of the true uncertainty of the spectral ratios.

Another problematic aspect must be addressed when the HVSR method is applied for the seismic microzonation of an area, that is, for its subdivision into areas relatively uniform with respect to their response to a seismic input. The experimental information with which we are facing this problem very often consists of a set of HVSR curves related to a fairly dense distribution of measurement points, and sometimes a little
NHESSD

2, 2597-2637, 2014

\section{Integration of HVSR measures and stratigraphic constraints \\ P. Di Stefano et al.}

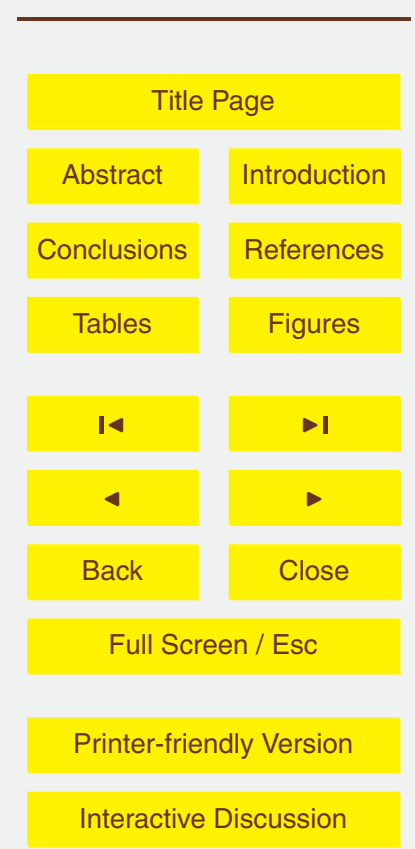


information about the subsurface from past geophysical and geological surveys and from some drilling.

Each HVSR curve may contain more significant peaks attributable to different causes namely different characteristics of the subsurface. This raises the problem of defining 5 the areas in which it is acceptable to assume the presence of the site effect due to a particular cause. In each interior point to that area, different from the measuring points, it will be reasonable to assume a site effect and characterize it in frequency and amplitude with a technique of 2-D interpolation of parameters determined at the measurement points.

10 In this paper, both the aforementioned problems, have been addressed by cluster analysis techniques described and assessed through some experimental tests (D’Alessandro et al., 2013).

To try to identify areas of the town of Oliveri probably interested in site effects and to define a preliminary subsurface model 23 HVSR measurements have been performed, quite uniformly distributed with a mean spacing of about $250 \mathrm{~m}$.

For the measurements has been used the $3 \mathrm{C}$ seismic digital station TROMINO ${ }^{\circledR}$ (Micromed), equipped with three velocity transducers.

For each measurement point the recording length was $46 \mathrm{~min}$ and the sampling frequency $256 \mathrm{~Hz}$. Each record was divided into 247 windows $10 \mathrm{~s}$ long. This choice allowed us to have a minimum numerosity of the sets of sampling windows selected for the analysis, with the clustering technique, not less than 150 (Sesame, 2004). Following the SESAME criteria, the signal relative to each time window was de-trended, baseline corrected, tapered and band pass filtered between 0.1 and $25 \mathrm{~Hz}$. Than we performed the FFT of each signal components and determined the HVSR curve following Konno and Ohmachi (1998). The analysis were limited to the frequency range $0.1-20 \mathrm{~Hz}$, which is the frequency range of interest for seismic microzonation and earthquake engineering. The data in the frequency domain have been filtered with a triangular window to obtain a smoothing of $10 \%$.

NHESSD

2, 2597-2637, 2014

Integration of HVSR measures and stratigraphic constraints

P. Di Stefano et al.

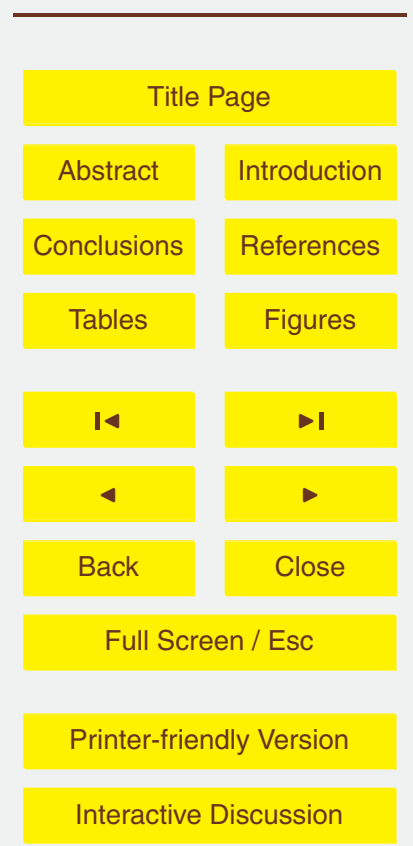


To determine the HVSR curves of each measurement point, we implemented a procedure based on an Agglomerative Hierarchical Clustering (AHC) algorithm. This has been selected by testing different hierarchical and non-hierarchical clustering algorithms. We used as proximity measure the Standard Correlation $\left(\mathrm{SC}_{x y}\right)$ and the average linkage (AL) criteria (D'Alessandro et al., 2014a).

This procedure allowed us to split, almost automatically, peaks probably linked to site effects from other perhaps related to source effects.

The separation of the two effects allowed us to determine for each cluster an average HVSR curve better related to the local site effects and to identify all the signif10 icant peaks of the $H / V$ spectra in the frequency range $0.6-20 \mathrm{~Hz}$. Their attribution to resonance phenomena of buried structures has been validated, in agreement with SESAME criteria, by analyzing the standard deviation of the spectral amplitudes and the independence from the azimuth of the mean spectral ratio (Fig. 3). Assuming an approximately one-dimensional ground around each measurement point, a peak of the 15 mean curve of a cluster have been attributed to characteristics of the subsoil only it is azimuthally stable.

In each HVSR curve all the significant peaks were identified and characterized by their center frequency and amplitude. These parameters are reported in Table 1.

The HVSR data (Fig. 4) have revealed the likely presence of amplification of ground

motion in the frequency range $0.7-2.6 \mathrm{~Hz}$, over a large part of the urban area. The thickness of the soft coverage in few places where it is known and its lithological composition allow us to hypothesize that the cause of amplification is the resonance of the same coverage.

\section{Frequency maps}

25 A clustering procedure may be also used to group peaks of HVSR average curves related to different sites, so as to identify areas characterized by site effects, which because of the similarity in frequency and amplitude of the corresponding HVSR peaks
NHESSD

2, 2597-2637, 2014

Integration of HVSR measures and stratigraphic constraints

P. Di Stefano et al.

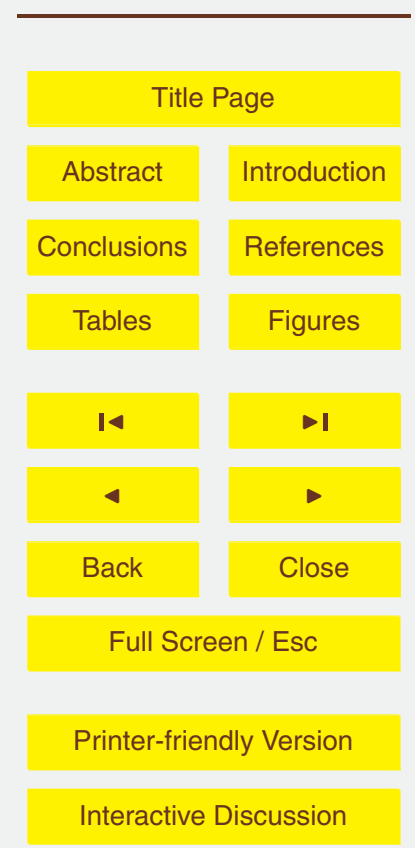


and the not excessive distance between the measuring points, are probably caused by the same buried structure. Considering the parameters of such peaks as sampling of spatial trends that are continuous on the area containing the measuring points, it is possible to estimate the expected peak amplitude and frequency at each point of the area by two-dimensional interpolation techniques.

To this end we implemented a clustering procedure to be applied to the parameter vectors that characterize the individual peaks. Each vector contains: period, amplitude, plane Cartesian coordinate and a parameter indicative of the outcropping lithology. The number of vectors is equal to the number of peaks considered significant. The proce10 dure is based on an Agglomerative Hierarchical Clustering (AHC) algorithm, using the average linkage $(A L)$ criteria. The elements of the similarity matrix are weighted averages of Euclidean relative distances between the quantitative parameters of a pair of peaks, while for the lithological parameter the distance has been set equal to 0 for coincident lithologies and 1 otherwise. Each difference between pairs of parameters is normalized by the maximum difference in the sample. To disadvantage the inclusion in the same cluster of more peaks relative to the same measurement point, the relative distance of coincident points was placed equal to 1 . The weight to be attributed to any type of parameter must be the result of an optimization that takes into account both parameters intrinsic to the clustering process and geological constraint (D'Alessandro et al., 2014b). For this application we set $w_{\text {per }}=0.4, w_{\text {ampl }}=0.2, w_{\text {dist }}=0.4, w_{\text {lith }}=0$.

The procedure of clustering made it possible to split the total set of peaks in four clusters referred to as: B (Blue), R (Red), G (Green), V (Violet), respectively, consisting of $21,12,7$, and 2 peaks. The cluster made up of only two peaks has been neglected in the overall description of the area due to poor reliability of both peaks, highlighted by the parameters listed in Table 1. Figure 5 shows the dendrogram of the clustering process. From this it is clear that, adopting a cut threshold slightly lower than the optimal one adopted by the calculation code, the three remaining clusters would be gathered in a single cluster.
NHESSD

2, 2597-2637, 2014

Integration of HVSR measures and stratigraphic constraints

P. Di Stefano et al.

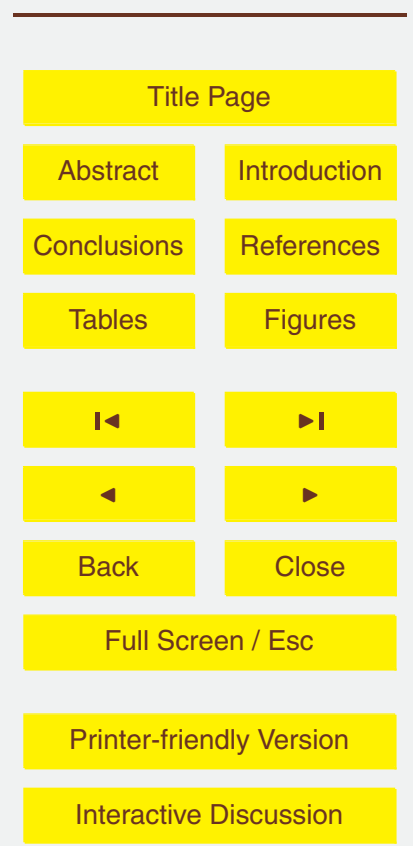


Figure 6 shows the characteristics of the clusters in the diagram $H / V$ vs. $F_{0}$ and their spatial distribution.

As the two clusters B and $G$ are very near in the scatter plot and their areas have an empty intersection, it was considered reasonable to assume that they represent the effects, continuously variable on the union of their areas, of a single source phenomenon. In particular it is assumed that $B$ and $G$ are related to the resonance effect of a covering layer delimited at its base by the same discontinuity surface with variable depth. Conversely it is assumed that the cluster $\mathrm{R}$, whose extent represent a significant part of that of $B \cup G$ and is characterized by higher frequencies respect to the corresponding ones of the peaks of $B \cup G$, show the resonance effects of the sedimentary cover down to a shallower interface.

Therefore, two different maps can be reconstructed, each of them grouping and separately representing the continuous trend of the frequency for the clusters $A \equiv B \cup G$ and $\mathrm{R}$. The amplification estimated at the measurement points is reported numerically in the maps, being not reliably mappable with smoothed trends over large areas.

For the processing of the maps, the kriging algorithm has been applied to interpolate the experimental peak frequencies at the nodes of a regular lattice with spacing equal to $10 \mathrm{~m}$. The frequency maps are plotted using a contour equidistance equal to 0.05 (Fig. 7).

20 An area south of the town, interesting for the spatial planning, seems to be characterized by higher amplification at frequencies greater than $1.2 \mathrm{~Hz}$ (Fig. 7, right).

\section{Seismic bedrock mapping by HVSR inversion}

For media consisting of homogeneous elastic or viscoelastic horizontal layers, it is possible to express the behaviour of $H / V$ vs. frequency for different mechanical pasimplifying assumptions about the composition of the microseismic field in terms of body and surface waves. For example that the microseismic field is totally constituted

NHESSD

2, 2597-2637, 2014

Integration of HVSR measures and stratigraphic constraints

P. Di Stefano et al.

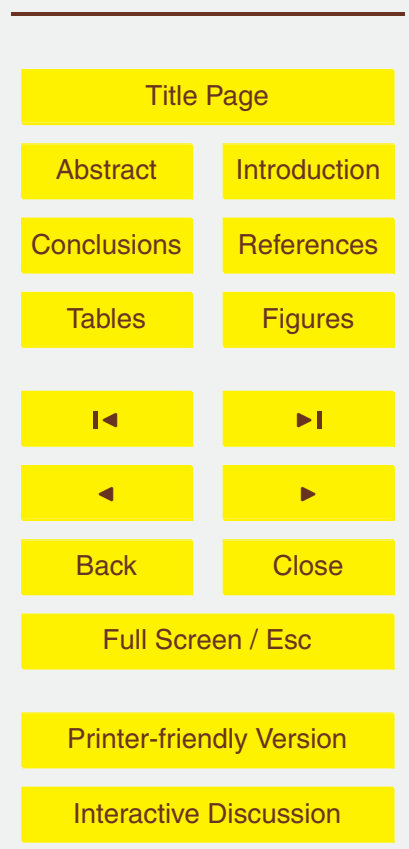


by body waves emerging almost vertically or totally by the fundamental mode of the Reyleigh waves.

Even with these simplistic assumptions, the determination of the parameters that characterize the subsoil from the $H / V(f)$ curves requires the solution of a nonlinear 5 inverse problem, poorly constrained by the experimental data and therefore highly nonunivocal and unstable, especially in complex cases as velocity inversions. The results will certainly be unreliable if you are not using an initial model already representative of the real geological stratification, because it is well constrained by drilling data, geological observations or results of other geophysical surveys mostly, in-hole seismic 10 surveys.

It should be, also, pointed out that, due to lateral variations of geologic parameters as: porosity, water content, fracturing degree, etc. the mechanical parameters of each layer will not be uniformly distributed with obvious negative consequences on the accuracy of the estimate of the depth of geological interfaces and in particular the roof of the seismic bedrock.

Taking into account the available geological information, the $H / V$ curves have been inverted to estimate the depth of the seismic bedrock, also reported in Table 1.

The inversion has been carried out using the Dinver inversion code developed in the frame of the project Geopsy (Wathelet et al., 2004; Wathelet, 2008). In this technique the computation of the dispersion curve for a stack of horizontal and homogeneous layers is determined (Haskell, 1953). Only the Rayleigh phase velocities are considered as the experimental dispersion curve is generally obtained from processing the vertical components of noise. As ambient vibrations may contain waves travelling in all directions, as body waves and Rayleigh and Love waves, a limit of this method lies in the uncertain composition of seismic noise and in the impossibility to include among the unknown parameters those relating to the model of the microseismic field (Peterson, 1993). For the inversion the neighbourhood algorithm (Sambridge, 1999) was used. This is a stochastic direct-search method for finding models of acceptable data fit inside a multidimensional parameter space.
NHESSD

2, 2597-2637, 2014

Integration of HVSR measures and stratigraphic constraints

P. Di Stefano et al.

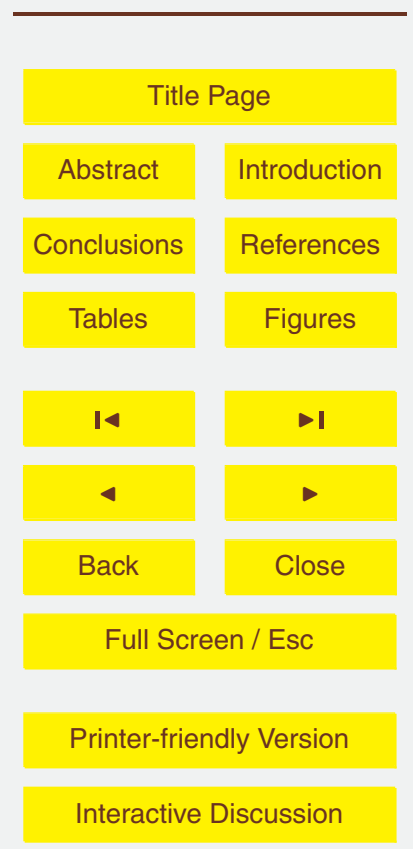


The a priori density of probability is set as uniform over the whole parameter space, the limits of which are defined by the a priori ranges of all chosen parameters. Once the data misfit function is determined, the neighbourhood algorithm provides a simple way of interpolating an irregular distribution of points, making use of Voronoi geometry 5 to find and investigate the most promising parts of the parameter space. Hence, the robustness of the final results is generally checked by running the same inversion several times with different random seeds, an integer value that initializes the pseudo-random generator.

Unfortunately, it has been possible to constrain the model using the data of a sin10 gle borehole, located at the eastern boundary of the municipality (Fig. 8), to impose constraints on the thicknesses of the layers in the inversion of the HVSR curve related to the nearest recording point. From this model estimates of the $S$ wave velocity were obtained, which were subsequently used to define the starting model for the inversion of the other HVSR curves.
The depth of transition of the shear wave velocity from less to greater than $800 \mathrm{~ms}^{-1}$ is considered the depth of the seismic bedrock. When evaluating the reliability of the estimate of this depth, we must consider that the trends represented are heavily influenced by the interpolation process between the HVSR measuring points. The depth values obtained from every measuring points are in fact only possible estimates, assuming minimal lateral variations. To avoid interpolation between depths of interfaces due to different geological structures, it was decided to group and correlate frequencies related to the same cluster. However it is not possible to exclude that frequencies belonging to the same cluster are due to different structures or vice versa.

In almost all the HVSR measurements carried out on the alluvial material a maximum peak is evident in the range $0.7-1.4 \mathrm{~Hz}$. This, by the inversions results, seems to be related to a variation of the shear-wave velocities that, under a depth of $40-60 \mathrm{~m}$ reach values attributable to a seismic bedrock (about $800 \mathrm{~m} \mathrm{~s}^{-1}$ ).

Analyzing the 1-D inverse models (Fig. 9) derived by inverting HVSR measurements, estimates of the depth of the seismic bedrock have been obtained. These, together with
NHESSD

2, 2597-2637, 2014

Integration of HVSR measures and stratigraphic constraints

P. Di Stefano et al.

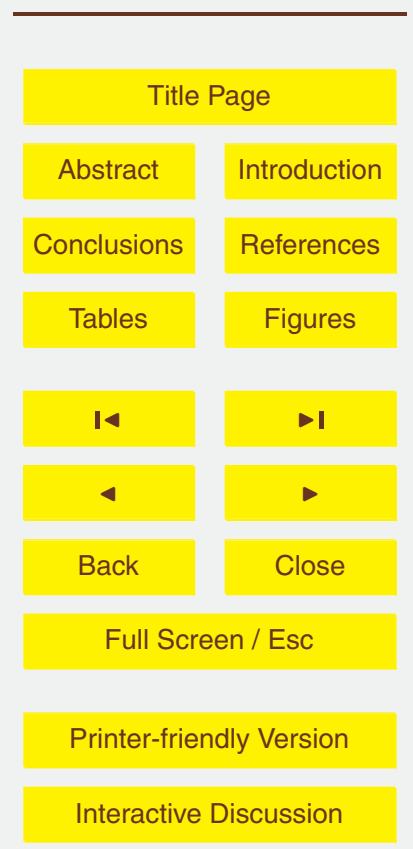


other reliable data like drilling and other geophysical surveys, were used to construct the map of the thickness of the sedimentary cover (Fig. 10, left) and the map of the altitude of the top of seismic bedrock a.s.l. (Fig. 10, right). The estimates of the depth of the bedrock were interpolated by imposing a constraint of a depth equal to zero in areas 5 where geological strata with elastic characteristics of seismic bedrock outcrop. The kriging interpolation algorithm was used, obtaining a lattice with equidistance between nodes equal to $10 \mathrm{~m}$.

The map of the bedrock depth contours was obtained by extracting from the Digital Elevation Model of the area a grid of points equidistant $50 \mathrm{~m}$. From these the corresponding lattice of the depth of the bedrock were subtracted. This choice was made in order to obtain a trend of the isobaths that was not excessively tied to topographic detail but which, however, did not present unrealistic areas with higher elevations of the topographic surface. It should however emphasize that the real detail of the maps can not be higher than the sampling density of the HVSR measurements, which generally 15 is not less than $300 \mathrm{~m}$.

Considering the geological configuration of the subsoil and the values of shear-wave velocity (deduced from direct bore-hole measurements) a preliminary identification was made of the geological structures that can cause seismic resonance.

For the above mentioned reasons the inversion of HVSR curves and evaluation of the 20 thickness of the cover did not take into account the available seismic down-hole data and instead, the mean values of shear-wave velocity of the cover, available in literature, were considered. In particular, we considered about 200 to $250 \mathrm{~m} \mathrm{~s}^{-1}$ for alluvium and about 350 to $400 \mathrm{~m} \mathrm{~s}^{-1}$ in correspondence of silty sands.

However the seismic velocity values used results close to those characteristic of the rock in the area.

On the basis of the 3-D trend of seismic bedrock and of geological information from field surveys and from published geological maps, three geological sections were drawn (Fig. 11).
NHESSD

2, 2597-2637, 2014

Integration of HVSR measures and stratigraphic constraints

P. Di Stefano et al.

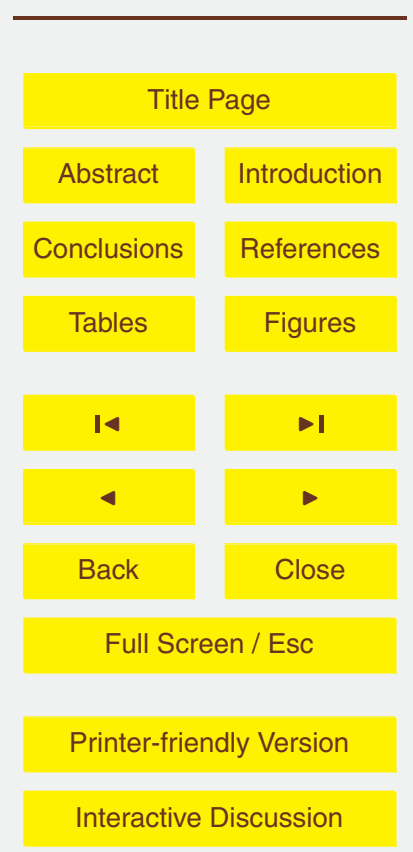


In the section A, oriented from west to east, it possible to observe, in the westernmost part, the stratigraphic overlay of the Flysch of Capo D'Orlando on the metamorphic substrate, which is lowered eastward by normal faults. The alluvial deposits of coastal plain are onlapping on the substrate whose lithology is not known in most of the area (sec5 tions $B$ and $C$ ) due to the lack of information deriving from deep boreholes. Therefore the only information is related to geophysical analysis. Along the Oliveri's plain some catalogs (e.g. ITHACA) and structural studies (Ghisetti and Vezzani,1977) testify the presence of an active fault that in geological sections is approximately shown.

\section{Geological-technical model}

10 The Oliveri's territory consists of a floodplain surrounded by mountains. These mountains are constituted by a metamorphic basement (Aspromonte Unit) covered by flysch and calcarenites sediments. The dominant lithology of this floodplain is sand with variable percentage of silt and clay and frequent alternations of silty-sandy gravels. The deposition of these sediments is related to the presence of two rivers, "Torrente Elicona" and "Torrente Castello", which cross the floodplain. The only outcrop, inner to the floodplain, is a hill, named "Il Castello", characterized by Gneiss of the Aspromonte Unit. This hill is the result of the morphological evolution of the Torrente Castello, in the northern side, while the southern side is bounded by buried faults. According to ITHACA catalogue the floodplain is crossed by a NNW-SSE normal fault named Tindari-Letojanni.

20 However, in the studied area, there are not morphological evidences that testify the existence of this fault (Ghisetti, 1979).

The lack of good data of wells has hampered the definition of the lithological distribution, in particular under the town. It is been possible to use only the data from two wells; the first is located close to Torrente Elicona, the second is located close to the Castello hill. The analysis of the core of the first well shows the presence of anthropic deposits in the first $1.6 \mathrm{~m}$, followed by $3.4 \mathrm{~m}$ of well graded sands with gravel elements of metamorphic origin, $5.5 \mathrm{~m}$ of silty sands, with rare rounded gravel elements, and $5.4 \mathrm{~m}$ of

\section{NHESSD}

2, 2597-2637, 2014

\section{Integration of HVSR measures and stratigraphic constraints \\ P. Di Stefano et al.}

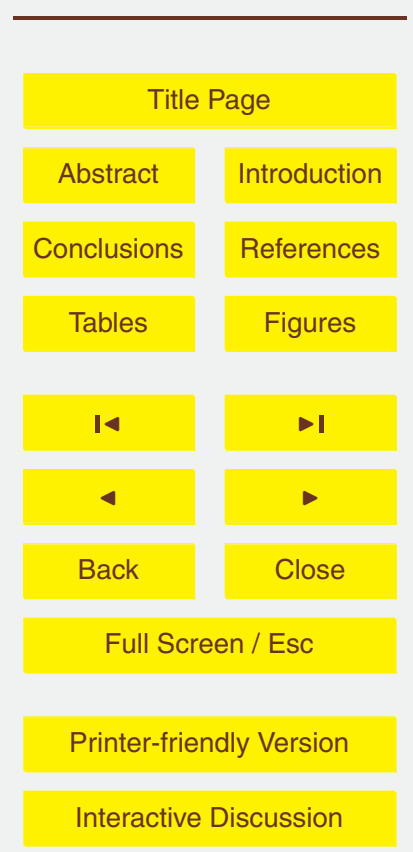


poorly graded sand. The altered substrate, according to its mechanical characterization by HVSR data, seems to be made by incoherent sand and grey silt. The analysis of core samples has permitted to recognize a bivalve mollusk fauna. The groundwater level is placed at a depth of $7.5 \mathrm{~m}$.

5 The core relative to the second well shows evidence of a tectonic dislocation that put in contact the "Argille Scagliose" unit with the metamorphic basement. This framework is also supported by geophysical data. From HVSR results it was possible to reconstruct the thickness of the coverage. In the northern side of Torrente Castello, the flyschoid coverage has a thickness of about $20 \mathrm{~m}$ while, in the southern part, the 10 thickness of clay and calcarenites coverages exceeds $45 \mathrm{~m}$ (Fig. 1). The nature of the coverages is related to the sedimentary contribution, of the rivers and of sea level fluctuations. Thanks to the interpretation of geophysical data it has been possible reconstruct the variation of the cover thickness in the studied area. The reconstructed model suggest the presence of two buried river beds separated by a relief. The sediment thickness in these two areas is about $45 \mathrm{~m}$. Using a DEM support was produced the seismic bedrock chart in which is possible to observe as the river beds have suffered a migration toward the present day position. In particular the Torrente Elicona was a little bit shifted while the other one, the Torrente Castello, was much moved north than today. According to the bedrock map the relief that separates the two depressions has a depth of $40 \mathrm{~m}$ while the floor of basins show a depth of $60-70 \mathrm{~m}$. In the southern part of the town there is another basin in which the bedrock reaches a deepness of $40 \mathrm{~m}$. This could be related to another minor river joined with the Torrente Elicona. Based on the hydrogeological map the presence of groundwater level in the floodplain is attested at a depth less than $15 \mathrm{~m}$. This condition renders the floodplain exposed to liquefaction 25 risk.
NHESSD

2, 2597-2637, 2014

\section{Integration of HVSR measures and stratigraphic constraints \\ P. Di Stefano et al.}

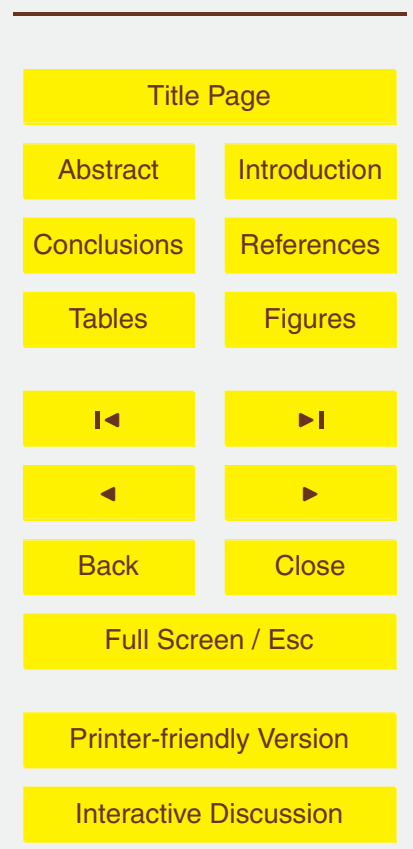




\section{Conclusions}

The main purpose of this work is not, of course, to present the complete results of the first level microzonation study carried out in an urban center of an area of high seismic hazard, but to show how a survey performed by the seismic noise HVSR technique, 5 thanks to some significant improvements in the processing procedure, can produce results that go far beyond the simple identification, in some recording points, of likely site effects at frequencies of engineering interest. The most innovative aspects of the processing of the recorded signals, underlying the significant improvement in the final result, are based on the use of clustering techniques in two phases of the study.

The application of a clustering procedure to the set of signals related to the elementary recording intervals, allowed a more objective identification and grouping in a cluster of the noise windows in which the spectral effects of the subsurface structures are dominant, compared to those dominated by trends attributable to spectral characteristics of the noise sources or to accidental interference effects between waves trains of a different nature.

The average spectral ratio of the cluster dominated by structural effects, often has been characterized by smaller variance of the frequencies and amplitudes of the significant peaks, compared to those of the peaks determined with standard methods.

The good quality of the estimates of frequency and amplitude of the peaks, allowed to use, with good results, a second clustering procedure to identify areas in the inside of which could be considered reasonable to interpolate the values of the parameters of peaks attributable to the effects of the same buried structures.

Assuming that the three identified clusters contain peaks produced by resonance effects of layers with varying thickness, it was possible to reconstruct the possible trend of the roof of the seismic bedrock by inversion of the HVSR curves constrained by all the geological and lithological available information and by a criterion of minimum lateral variability of the physical and geometrical parameters. Although the reliability of the 3-D model obtained is limited by the lack of geophysical and drilling data, which
NHESSD

2, 2597-2637, 2014

Integration of HVSR measures and stratigraphic constraints

P. Di Stefano et al.

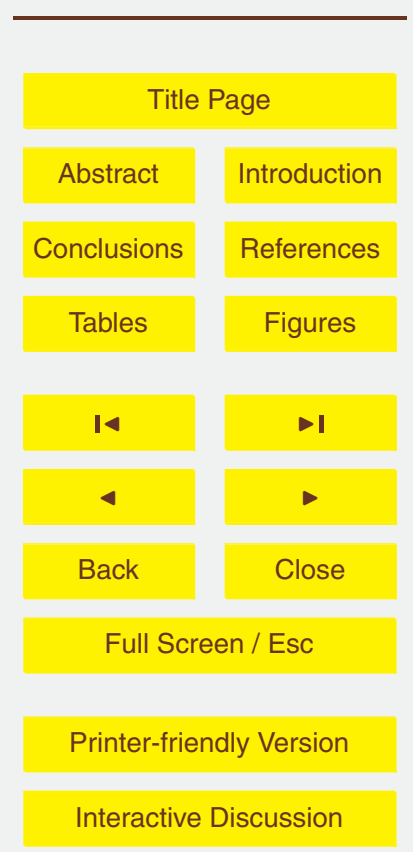


would have allowed us to better constrain the values of the unknown parameters of the model, however the general characteristics of the reconstructed subsoil portion are fully compatible with the geological data. The investigations necessary to increase the resolution and reliability of the model will be carried out in-depth studies provided by

\section{References}

Abate, D., De Pippo, T., Ilardi, M., and Pennetta, M.: Studio delle caratteristiche morfoevolutive quaternarie della piana del Garigliano, II Quaternario, 11, 149-158, 1998.

Adelfio, G., Chiodi, M., De Luca, L., Luzio, D., and Vitale, M.: Southern-Tyrrhenian seismicity in space-time-magnitude domain, Ann. Geophys.-Italy, 49, 1245-1257, 2006.

Arai, $\mathrm{H}$. and Tokimatsu, K.: $S$ wave velocity profiling by inversion of microtremor $\mathrm{H} / \mathrm{V}$ spectrum, B. Seismol. Soc. Am., 94, 53-63, 2004.

Barbano, M. S., Bottari, A., Carveni, P., Cosentino, M., Federico, B., Fonte, G., Lo Giudice, E., Lombardo, G., and Patanè, G.: Macroseismc study of the gulf of Patti earthquake in the geostructural frame of the North-Eastern Sicily, Bollettino della Società Geologica Italiana, 98, 155-174, 1979.

Bard, P. Y.: Microtremor measurements: a tool for site effect estimation?, in: The Effects of Surface Geology on Seismic Motion. Balkema, edited by: Irikura, K., Kudo. K., Okada, H., and Sasatami, T., Rotterdam, 3, 1251-1279, 1999.

Ben-Menahem, A. and Singh, S. J.: Seismic Waves and Sources, Springer-Verlag, New York, 1981.

Boccaletti, M., Tortorici, L., and Ferrini, G. L.: The Calabrian Arc in the frame of the evolution of the Tyrrhenian Basin, in: Paleogeography and Geodynamics of the Perityrrhenian Area, edited by: Boccaletti, M., Gelati, R. Ricci Lucchi, F., and Pepe, F., Giorn. Geol., 48, 113-120, 1986.

Borcherdt, R. D.: Effects of local geology on ground motion near San Francisco Bay, B. Seismol. Soc. Am., 60, 29-61, 1970.

Catalano, S. and Di Stefano, A.: Sollevamenti e tettogenesi pleistocenica lungo il margine tirrenico dei Monti Peloritani: integrazione dei dati geomorfologici, strutturali e biostratigrafici, II

NHESSD

2, 2597-2637, 2014

Integration of HVSR measures and stratigraphic constraints

P. Di Stefano et al.

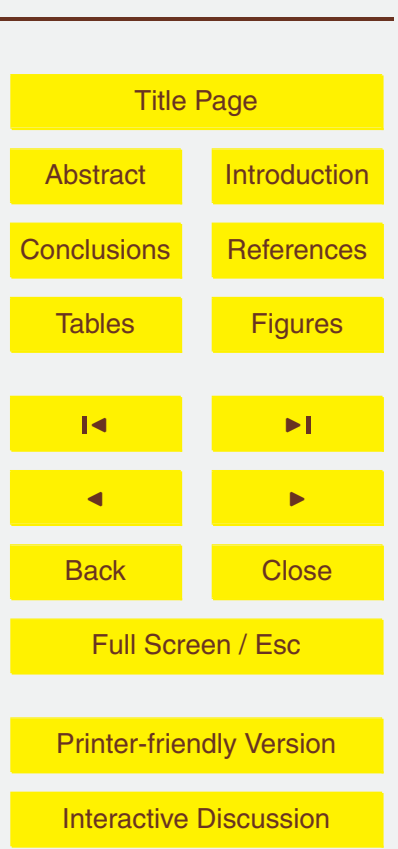


D’Alessandro, A., Capizzi, P., Luzio, D., Martorana, R., and Messina, N.: Improvement of HVSR technique by cluster analysis, Geoitalia 2013, IX FIST, Pisa, 16-18 Settembre 2013, 2013.

D’Alessandro, A., Luzio, D., Capizzi, P., and Martorana, R.: Improvement of seismic microzonation by means of cluster analysis, in preparation, 2014a.

5 D'Alessandro, A., Luzio, D., Martorana, and R., Capizzi, P.: Improvement of the noise Horizontal to Vertical Spectral Ratio by cluster analysis, in preparation, 2014b.

De Guidi, G., Lanzafame, G., Palano, M., Puglisi, G., Scaltrito, A., and Scarfi, L.: Multidisciplinary study of the Tindari Fault (Sicily, Italy) separating ongoing contractional and extensional compartments along the active Africa-Eurasia convergent boundary, Tectonophysics, $10 \quad 588,1-17,2013$.

De Rubeis, V., Cultrera, G., Cadet, H., Bard, P. Y., and Theodoulidis, N.: Statistical estimation of earthquake site response from noise recordings, 4th IASPEI/IAEE International Symposium: Effects of Surface Geology on Seismic Motion, ESG4, 2011.

Di Stefano, E., Agate, M., Incarbona, A., Russo, F., Sprovieri, R., and Bonomo, S.: Late Qua15 ternary high uplift rates in northeastern Sicily: evidence from calcareous nannofossils and benthic and planktonic foraminifera, Facies, 58, 1-15, 2012.

Dimitriu, P., Theodulidis, N., and Bard, P. Y.: Evidence of non linear site in HVSR from SMART1 (Taiwan) data, Soil Dyn. Earthq. Eng., 20, 155-165, 2000.

Fäh, D., Kind, F., and Giardini, D.: A theoretical investigation of average HIV ratios, Geophys. J. Int., 145, 535-549, 2001.

Fäh, D., Kind, F., and Giardini, D.: Inversion of local $S$ wave velocity structures from average $H / V$ ratios, and their use for the estimation of site-effects, J. Seismol., 7, 449-467, 2003.

Field, E. H. and Jacob, K. H.: The theoretical response of sedimentary layers to ambient seismic noise, Geophys. Res. Lett., 20, 2925-2928, 1993.

Field, E. H. and Jacob, K. H.: A comparison and test of various site response estimation techniques, including three that are not reference site dependent, B. Seismol. Soc. Am., 85, 4, 1127-1143, 1995.

Finetti, I.: Structural, stratigraphy and evolution of central Mediterranean, Boll. Geof. Teor. Appl., 24, 247-312, 1982.

30 Finetti, I. and Del Ben, A.: Geophysical study of the Tyrrhenian opening, Boll. Geof. Teor. Appl., 28, 75-155, 1986.

\section{NHESSD}

2, 2597-2637, 2014

Integration of HVSR measures and stratigraphic constraints

P. Di Stefano et al.

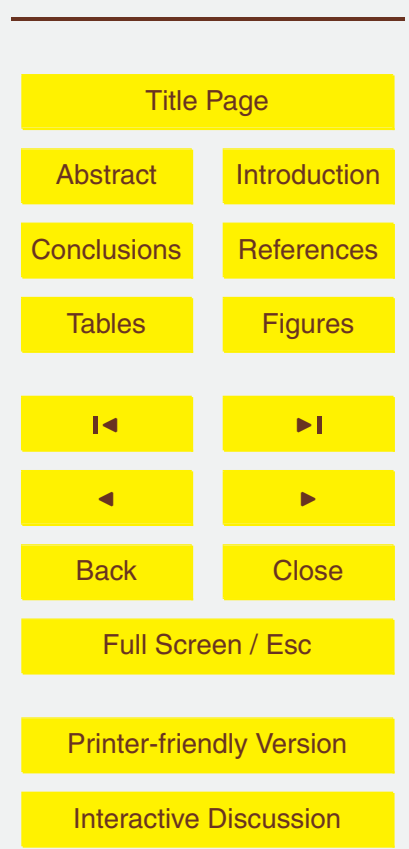


Finetti, I. R., Lentini, F., Carbone, S., Catalano, S., and Del Ben, A.: II Sistema Appennino Meridionale-Arco Calabro-Sicilia nel Mediterraneo centrale: studio geologico-geofisico, Boll. Soc. Geol. It., 115, 529-559, 1996.

Ghisetti, F.: Relazioni tra strutture e fasi trascorrenti e distensive lungo i sistemi Messina5 Fiumefreddo, Tindari-Letojanni e Alia-Malvagna (Sicilia nord-orientale): uno studio microtettonico, Geol. Rom., 18, 23-58, 1979.

Ghisetti, F.: Fault parameters in the Messina Strait (southern Italy) and relations with the seismogenic source, Tectonophysics, 210, 117-133, 1992.

Ghisetti, F. and Vezzani, L.: Evidenze di linee di dislocazione sul versante meridionale dei Monti Nebrodi e Madonie e loro significato neotettonico, Boll. Geodesia e Sc. affini, 36, 411-437, 1977.

Ghisetti, F. and Vezzani, L.: Thin-skinned deformations of the western Sicily thrust belt and relationships with crustal shortening: mesostructural data on the Mt. Kumeta-Alcantara Fault Zone and related structures, Boll. Soc. Geol. It., 103, 129-157, 1984.

Giammanco, S., Palano, M., Scaltrito, A., Scarfi, L., and Sortino, F.: Possible role of fluid overpressure in the generation of earthquake swarms in active tectonic areas: the case of the Peloritani Mts. (Sicily, Italy), J. Volcanol. Geoth. Res., 178, 795-806, doi:10.1016/j.jvolgeores.2008.09.005, 2008.

Giunta, G.: Elementi per un modello cinematico delle maghrebidi siciliane, Mem. Soc. Geol. It., 47, 297-311, 1991.

Giunta, G. and Nigro, F.: Some tectono-sedimentary constraints to Oligo-Miocene evolution of the Peloritani Thrust Belt, Tectonophysics, 315, 287-299, 1998.

Giunta, G. and Somma, R.: Nuove osservazioni sulla struttura dell'Unità di Alì (M.ti Peloritani, Sicilia), Boll. Soc. Geol. It., 115, 489-500, 1996.

Giunta, G., Messina, A., Bonardi, G., Nigro, F., Somma, R., Cutrupia, D., Giorgianni, A., and Sparacino, V.: Geologia dei Monti Peloritani (Sicilia NE), Guida all'escursione, $77^{\circ}$ Riunione estiva, Palermo, 1998.

Giunta, G., Nigro, F., Renda, P., and Giorgianni, A.: The Sicilian-Maghrebides Tyrrhenian Margin: a neotectonic evolutionary model, Mem. Soc. Geol. It., 119, 553-565, 2000.

30 Giunta, G., Luzio, D., Tondi, E., De Luca, L., Giorgianni, A., D’Anna, G., Renda, P., Cello, G., Nigro, F., and Vitale, M.: The Palermo (Sicily) seismic cluster of September 2002, in the seismotectonic framework of the Tyrrhenian Sea-Sicily border area, Ann. Geophys.-Italy, 47, 1755-1770, 2004.
NHESSD

2, 2597-2637, 2014

Integration of HVSR measures and stratigraphic constraints

P. Di Stefano et al.

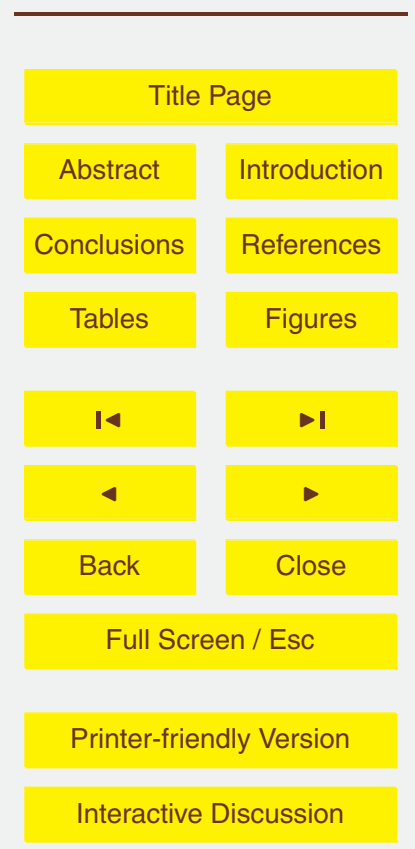


Guerrera, F. and Wezel, F. C.: Nuovi dati stratigrafici sui flysch oligomiocenici siciliani e considerazioni tettoniche relative, Riv. Min. Sic., 145-147, 27-51, 1974.

Guidoboni, E., Ferrari, G., Mariotti, D., Comastri, A., Tarabusi, G., and Valensise, G.: Catalogue of Strong Earthquakes in Italy (CFTI), 461BC-1997 and Mediterranean Area 760BC-1500,

5 available at: http://storing.ingv.it/cfti4med/, 2007.

Horike, M., Zhao, B., and Kawase, H.: Comparison of site response characteristics inferred from microtremors and earthquake shear waves, B. Seismol. Soc. Am., 91, 1526-1536, 2001.

Konno, K. and Ohmachi, T.: Ground-motion characteristics estimated from spectral ratio between horizontal and vertical components of microtremor, B. Seismol. Soc. Am., 88, 1, $228-$ $10 \quad 241,1998$.

Kudo, K.: Practical estimates of site response, State-of-the-Art report, In: Proceedings of the Fifth International Conference on Seismic Zonation, 17-19 October, Nice, France, Ouest Editions Nantes, 3, 1878-1907, 1995.

Lachet, C. and Bard, P. Y.: Numerical and theoretical investigations on the possibilities and 15 limitations of Nakamura's technique, J. Phys. Earth, 42, 377-397, 1994.

Lermo, J., Francisco, S., and Chavez-Garcia, J.: Site Effect Evaluation using microtremors: a review (abstract), EOS, 73, 352, 1992.

Malinverno, A. and Ryan, W. B. F.: Extension in the Tyrrhenian Sea and shortening in the Apennines as results of arc migration driven by sinking of the lithosphere, Tectonics, 5, 227$20 \quad 245,1986$.

Mauz, B. and Renda, P.: Tectonic features at the NW-coast of Sicily (Gulf of Castellammare), Implications for the Plio-Pleistocene structural evolution of the southern Tyrrhenian continental margin, Studi Geol. Cam., 2, 343-349, 1995.

Meletti, C. and Valensise, G.: Zonazione sismo genetica ZS9 - A 2 pp. al Rapporto Conclusivo, 25 available at: http://zonesismiche.mi.ingv.it/documenti/A2pp.pdf, 2004.

Monaco, C. and Tortorici, L.: Tectonic role of ophiolite-bearing terranes in the development of the southern Apennines orogenic belt, Terra Nova, 7, 153-160, 1995.

Mucciarelli, M.: Reliability and applicability of Nakamura's technique using microtremors: an experimental approach, J. Earthq. Eng., 2, 625-638, 1998.

30 Mucciarelli, M. and Gallipoli, M. R.: The HVSR technique from microtremor to strong motion: empirical and statistical considerations, 13th World Conference on Earthquake Engineering, Vancouver, BC, Canada, 1-6 August 2004, 45, 2004.

NHESSD

2, 2597-2637, 2014

Integration of HVSR measures and stratigraphic constraints

P. Di Stefano et al.

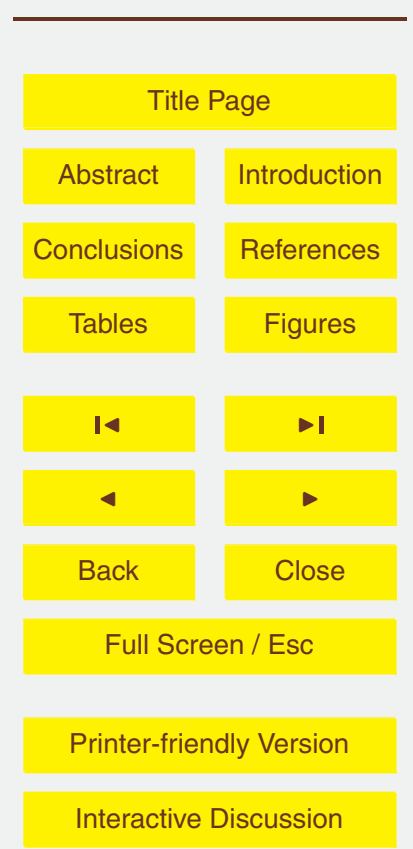


Mucciarelli, M., Gallipoli, M. R., and Arcieri, M.: The stability of the horizontal-to-vertical spectral ratio of triggered noise and earthquake recordings, B. Seismol. Soc. Am., 93, 1407-1413, 2003.

Nakamura, Y.: A Method for Dynamic Characteristics Estimation of Subsurface using Mi5 crotremor on the Ground Surface, Quarterly Report of Railway Technical Research Institute (RTRI), 30, 1, 1989.

Nakamura, Y.: Clear Identification of Fundamental Idea of Nakamura's Technique and its Applications, 12th World Conference on Earthquake Engineering, 2656, 2000.

Neri, G., Caccamo, D., Cocina, O., and Montalto, A.: Geodynamic implications of earthquake data in the southern Tyrrhenian sea, Tectonophysics, 258, 233-249, 1996.

Neri, G., Barberi, G., Orecchio, B., and Mostaccio, A.: Seismic strain and seismogenic stress regimes in the crust of the southern Tyrrhenian region, Earth Planet. Sc. Lett., 213, 97-112, 2003.

Nigro, F.: L'Unità Longi-Taormina. Stratigrafia e Tettonica Delle Coperture Mesozoico-Terziarie 15 Dell'elemento Peloritano Occidentale, Tesi di Dottorato, Palermo, 276 pp., 1994.

Nigro, F.: Neotectonic events and kinematic of rhegmatic-like basins in Sicily and adjacent areas, Implications for a structural model of the Tyrrhenian opening, Boll. Soc. Geol. Pol., 69, $1-18,1998$.

Nigro, F. and Renda, P.: Evoluzione geologica ed assetto strutturale della Sicilia centrosettentrionale, Boll. Soc. Geol. It., 118, 375-388, 1999.

Nigro, F. and Renda, P.: Un modello di evoluzione tettono-sedimentaria dell'avanfossa neogenica siciliana, Boll. Soc. Geol. It., 119, 667-686, 2000.

Nigro, F. and Renda, P.: Forced mode dictated by foreland fault-indenter shape during oblique convergence: the Western Sicily mainland, Boll. Soc. Geol. It., 121, 151-162, 2002.

Nigro, F. and Renda, P.: Pilo-Pleistocene strike-slip deformation in NE Sicily: the example of the area between Capo Calavà, Bollettino della Società Geologica Italiana, 124, 377-394, 2005.

Nigro, F. and Sulli, A.: Plio-Pleistocene extensional tectonics in the Western Peloritani area and its offshore, Tectonophysics, 252, 295-305, 1995.

30 Ogniben, L.: Nota illustrativa dello Schema geologico della Sicilia nord-orientale, Riv. Min. Sic., 64-65, 183-212, 1960.

Ogniben, L.: Schema introduttivo alla geologia del confine calabro-lucano, Mem. Soc. Geol. It., 8, 453-463, 1969.
NHESSD

2, 2597-2637, 2014

Integration of HVSR measures and stratigraphic constraints

P. Di Stefano et al.

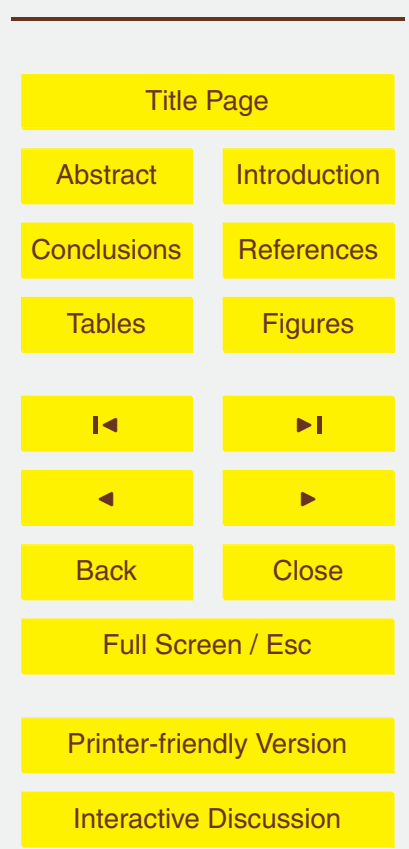


Ogniben, L.: Schemi paleotettonici anzichè paleogeografici in regioni di corrugamento: l'esempio della Sicilia, Mem. Soc. Geol. It., 9, 793-816, 1970.

Panou, A. A., Theodulidis, N., Hatzidimitriou, P., Stylianidis, K., and Papazachos, C. B.: Ambient noise horizontal-to-vertical spectral ratio in site effects estimation and correlation with seismic

5 damage distribution in urban environment: the case of the city of Thessaloniki (Northern Greece), Soil Dyn. Earthq. Eng., 25, 261-274, 2005.

Parolai, S., Bindi, D., and Augliera, P.: Application of the Generalized Inversion Technique (GIT) to a microzonation study: numerical simulations and comparison with different site-estimation techniques, B. Seismol. Soc. Am., 90, 286-297, 2000.

10 Parolai, S., Picozzi, M., Richwalski, S. M., and Milkereit, C.: Joint inversion of phase velocity dispersion and $H / V$ ratio curves from seismic noise recordings using a genetic algorithm, considering higher modes, Geophys. Res. Lett., 32, 1-4, 2005.

Parolai, S., Richwalski, S. M., Milkereit, C., and Fäh, D.: $S$ wave velocity profiles for earthquake engineering purposes for the Cologne area (Germany), Bulletin of Earthquake Engineering, 4, 65-94, 2006.

Peterson, J.: Observations and modeling of seismic background noise, Open-File Report, US Geological Survey, Albuquerque, N M., 93-322, 1993.

Picozzi, M., Parolai, S., and Richwalski, S. M.: Joint inversion of $H / V$ ratios and dispersion curves from seismic noise: estimating the $S$ wave velocity of bedrock, Geophys. Res. Lett., $20 \quad 32,1-4,2005$.

Rodríguez, M., Chávez-García, F. J., and Stephenson, W. R.: Site effects in an alluvial valley: a comparison of estimates from earthquake and microtremor records, Proc. 12th World Conference on Earthquake Engineering, Auckland, New Zealand, New Zealand Society for Earthquake Engineering, Article Id. 1441, 2000.

Sambridge, M.: Geophysical inversion with a neighbourhood algorithm - I. Searching a parameter space, Geophys. J. Int., 103, 4839-4878, 1999.

Scherbaum, F., Hinzen, K.-G., and Ohrnberger, M.: Determination of shallow shear wave velocity profiles in the cologne, Germany area using ambient vibrations, Geophys. J. Int., 152, 597-612, 2003.

30 SESAME Project: Guidelines for the implementation of the $H / V$ spectral ratio technique on ambient vibrations, Measurements, processing and interpretation, WP12, deliverable no. D23.12, available at: http://sesame-fp5.obs.ujf-grenoble.fr/Papers/HV_User_Guidelines.pdf, (2004).

NHESSD

2, 2597-2637, 2014

Integration of HVSR measures and stratigraphic constraints

P. Di Stefano et al.

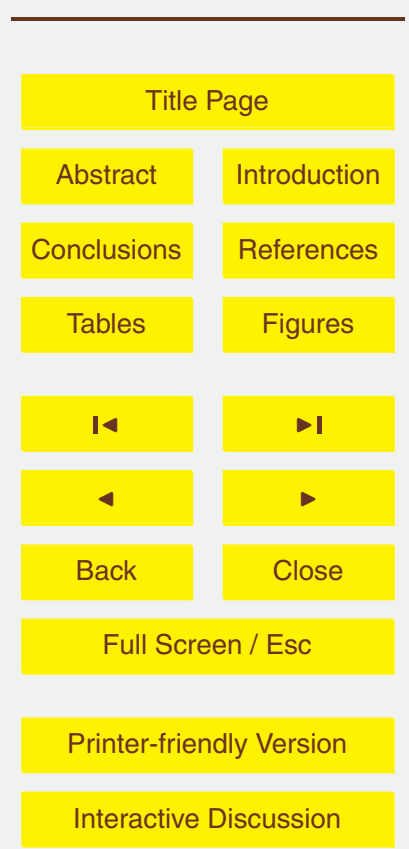


Tinti, S. and Mulargia, F.: Confidence intervals of bvalues for grouped magnitudes, B. Seismol. Soc. Am., 77, 2125-2134, 1987.

Valensise, G. and Pantosti, D.: A 125 kyr-long geological record of seismic source repeatability: the Messina Straits (southern Italy) and the 1908 earthquake (Ms 7 1/2), Terra Nova, 4, 472-483, 1992.

Wathelet, M.: An improved neighborhood algorithm: parameter conditions and dynamic scaling, Geophys. Res. Lett., 35, L09301, doi:10.1029/2008GL033256, 2008.

Wathelet, M., Jongmans, D., and Ohrnberger, M.: Surface wave inversion using a direct search algorithm and its application to ambient vibration measurements, Near Surf. Geophys., 2, 211-221, 2004.

Yuncha, Z. A. and Luzon, F.: On the horizontal-to-vertical spectral ratio in sedimentary basins, B. Seismol. Soc. Am., 90, 1101-1106, 2000.

\section{NHESSD}

2, 2597-2637, 2014

Integration of HVSR measures and stratigraphic constraints

P. Di Stefano et al.

Title Page

Abstract

Conclusions

\section{Tables}

14

4

Back

Full Screen / Esc

Printer-friendly Version 
Table 1. Measurement points, UTM coordinates, frequencies of the significant peaks, $H / V$ ratios.

\begin{tabular}{llllll}
\hline ID & Longitude & Latitude & Frequency $(\mathrm{Hz})$ & Amplitude & Cluster \\
\hline 1 & 15.066871 & 38.125908 & 0.73 & 4.49 & 1 \\
2 & 15.063414 & 38.126892 & 1.23 & 7.64 & 1 \\
3 & 15.059912 & 38.127903 & 0.76 & 3.80 & 1 \\
3 & 15.059912 & 38.127903 & 1.13 & 4.23 & 1 \\
4 & 15.057073 & 38.129833 & 0.77 & 8.12 & 1 \\
5 & 15.055261 & 38.132241 & 0.82 & 5.96 & 1 \\
6 & 15.055074 & 38.127563 & 1.03 & 6.17 & 1 \\
7 & 15.056796 & 38.126292 & 1.00 & 5.35 & 1 \\
8 & 15.059567 & 38.124235 & 1.00 & 5.10 & 1 \\
8 & 15.059567 & 38.124235 & 1.78 & 3.19 & 2 \\
9 & 15.062717 & 38.125018 & 0.84 & 6.08 & 1 \\
9 & 15.062717 & 38.125018 & 1.10 & 7.09 & 1 \\
10 & 15.065124 & 38.124719 & 0.77 & 6.48 & 1 \\
10 & 15.065124 & 38.124719 & 1.10 & 4.30 & 1 \\
11 & 15.065406 & 38.121772 & 0.83 & 4.21 & 1 \\
11 & 15.065406 & 38.121772 & 1.43 & 4.51 & 1 \\
12 & 15.062658 & 38.122990 & 0.93 & 4.68 & 1 \\
13 & 15.064252 & 38.119654 & 1.53 & 6.00 & 1 \\
14 & 15.060934 & 38.121026 & 1.10 & 3.56 & 1 \\
14 & 15.060934 & 38.121026 & 1.37 & 2.55 & 1 \\
14 & 15.060934 & 38.121026 & 1.73 & 2.71 & 2 \\
15 & 15.057181 & 38.121650 & 1.83 & 3.22 & 2 \\
16 & 15.054749 & 38.118991 & 0.90 & 4.28 & 3 \\
16 & 15.054749 & 38.118991 & 1.53 & 4.35 & 2 \\
16 & 15.054749 & 38.118991 & 10.14 & 3.10 & 4 \\
17 & 15.051740 & 38.122412 & 0.90 & 2.57 & 3 \\
17 & 15.051740 & 38.122412 & 1.70 & 3.24 & 2 \\
17 & 15.051740 & 38.122412 & 2.67 & 4.94 & 2 \\
18 & 15.049392 & 38.119468 & 0.87 & 2.60 & 3 \\
18 & 15.049392 & 38.119468 & 1.50 & 2.67 & 2 \\
19 & 15.046962 & 38.114408 & 0.87 & 3.12 & 3 \\
19 & 15.046962 & 38.114408 & 2.20 & 4.23 & 2 \\
19 & 15.046962 & 38.114408 & 6.08 & 2.80 & 4 \\
20 & 15.051695 & 38.116305 & 0.97 & 4.00 & 3 \\
20 & 15.051695 & 38.116305 & 1.43 & 4.54 & 2 \\
21 & 15.054697 & 38.114280 & 0.87 & 3.31 & 3 \\
21 & 15.054697 & 38.114280 & 1.37 & 4.41 & 2 \\
21 & 15.054697 & 38.114280 & 1.73 & 4.31 & 2 \\
22 & 15.050217 & 38.111984 & 0.87 & 4.10 & 3 \\
22 & 15.050217 & 38.111984 & 1.23 & 5.39 & 2 \\
23 & 15.058505 & 38.118050 & 0.77 & 3.83 & 1 \\
23 & 15.058505 & 38.118050 & 1.30 & 3.63 & 1 \\
\hline & & & & &
\end{tabular}

\section{NHESSD}

2, 2597-2637, 2014

\section{Integration of HVSR measures and stratigraphic constraints}

P. Di Stefano et al.

\section{Title Page}

\begin{tabular}{|c|c|}
\hline Abstract & Introduction \\
\hline Conclusions & References \\
\hline Tables & Figures \\
\hline B & \\
\hline & \\
\hline Back & \\
\hline Full Screen / Esc \\
\hline Printer-friendly Version \\
\hline Interactive Discussion
\end{tabular}




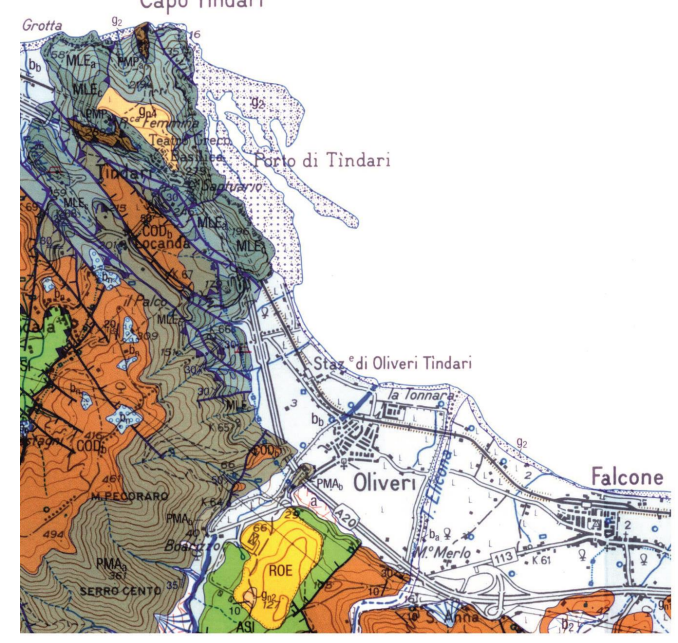

\section{NHESSD}

2, 2597-2637, 2014

\section{Integration of HVSR measures and stratigraphic constraints}

P. Di Stefano et al.

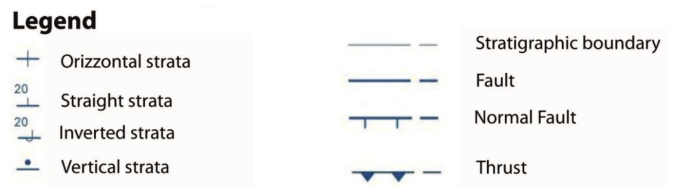

Fig. 1. Geological map of Oliveri town (from SERVIZIO GEOLOGICO D'ITALIA (2011) - "Foglio Geologico 600 Barcellona Pozzo di Gotto" 1:50000 CARG-ISPRA): a) slope debris; $b_{a}$ ) active alluvial deposits; $b_{b}$ ) alluvial and litoral deposits; $b_{2}$ ) eluvium and colluvium; $b_{n}$ ) inactive alluvial terraced deposits; $g_{2}$ ) active strandlines (beaches); $g_{n 1--5}$ ) terraced marine deposits; ROE Biodetrital calcarenites, clays and sandy clays (Rometta Fm., Upper Pliocene-Middle Pleistocene); ASI) Argille Scagliose (Upper Cretaceous); $\mathrm{COD}_{b-c}$ ) Capo d'Orlando Flysch: areanaceous facies (arkose) with alternation of clay-marly levels (Upper Oligocene-lower Burdigalian); $\mathrm{PMA}_{a-b}$ ) paragneiss and gneissic micaschists, silicate marbles, quartzites and aplo-pegmatitic dykes $\left(\mathrm{PMP}_{a}\right)$ (Apromonte unit-Paleo-Proterozoic-Permian); $\mathrm{MLE}_{a-b-c}$ ) Paragneiss, micaschists, marbles, eclogites, quartzites (Mela unit-Paleozoic). 


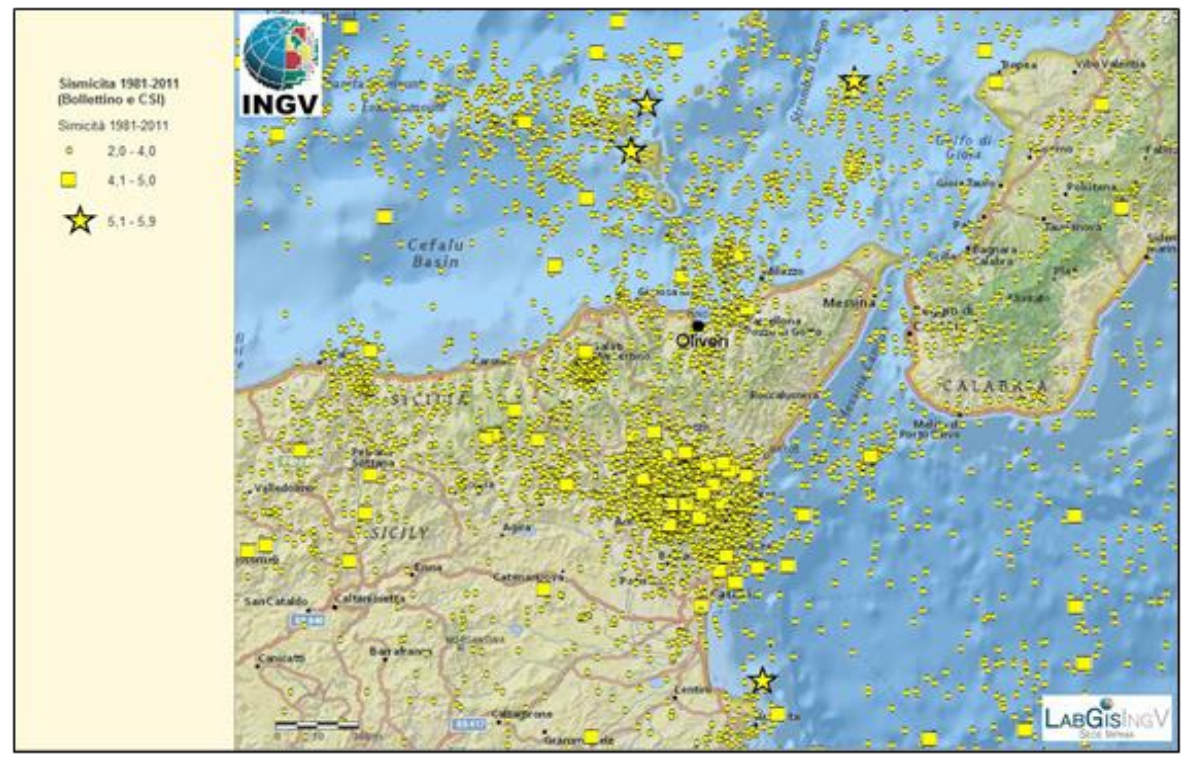

Fig. 2. Distribution of epicenters of instrumental earthquakes located by the INGV between 1981 and 2011.

\section{NHESSD}

2, 2597-2637, 2014

Integration of HVSR measures and stratigraphic constraints

P. Di Stefano et al.

Title Page

\begin{tabular}{|c|c|}
\hline Abstract & Introduction \\
\hline Conclusions & References \\
\hline Tables & Figures \\
\hline I4 & \\
\hline & \\
\hline Back & \\
\hline Full Screen / Esc \\
\hline Printer-friendly Version \\
\hline Interactive Discussion
\end{tabular}



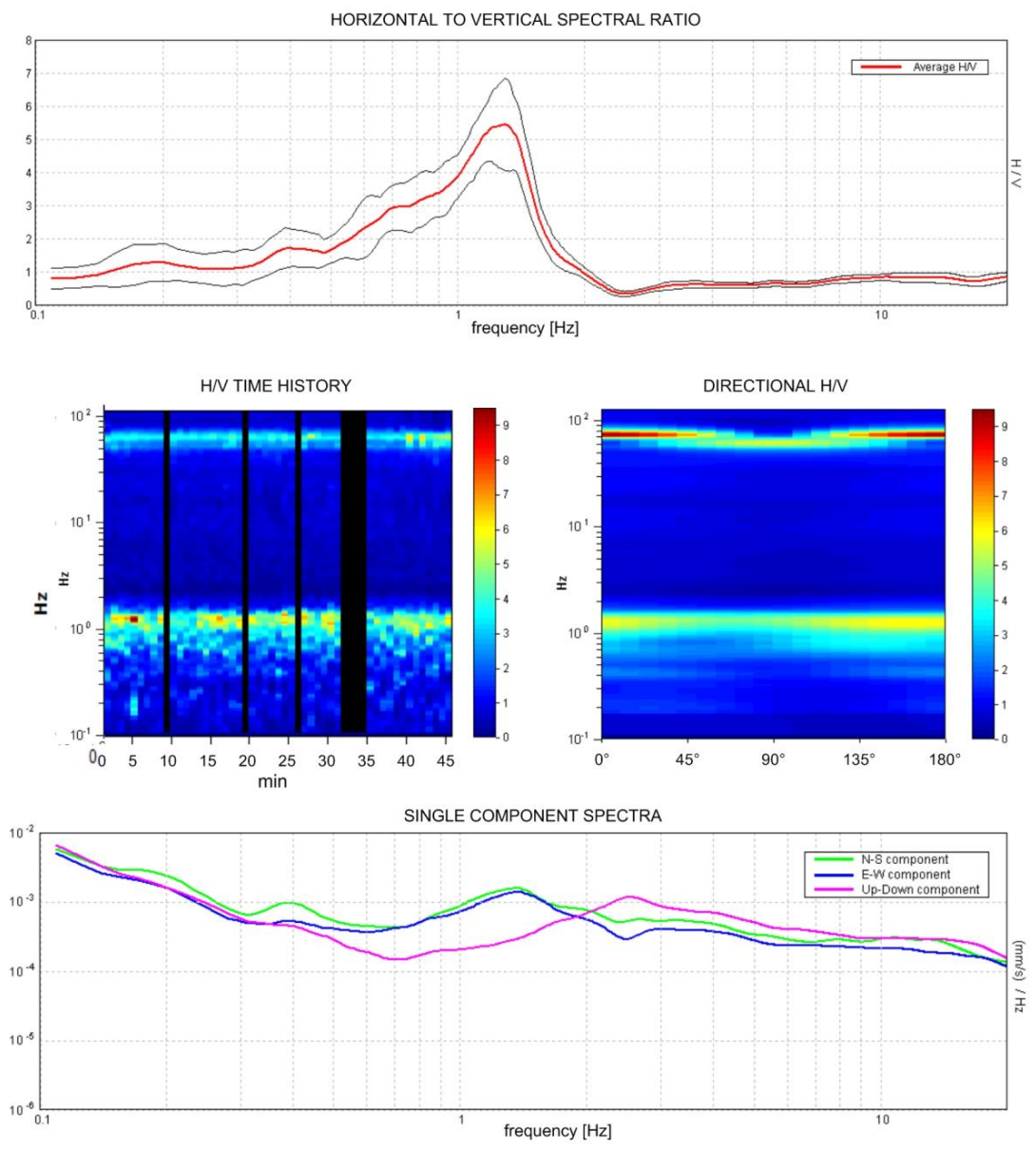

Fig. 3. HVSR analysis of the microtremor record nr. 2.

\section{NHESSD}

2, 2597-2637, 2014

Integration of HVSR measures and stratigraphic constraints

P. Di Stefano et al.

Title Page

\begin{tabular}{|c|c|}
\hline Abstract & Introduction \\
\hline Conclusions & References \\
\hline Tables & Figures \\
\hline I4 & \\
\hline & \\
\hline Back & Close \\
\hline Full Screen / Esc \\
\hline
\end{tabular}

Printer-friendly Version

Interactive Discussion 


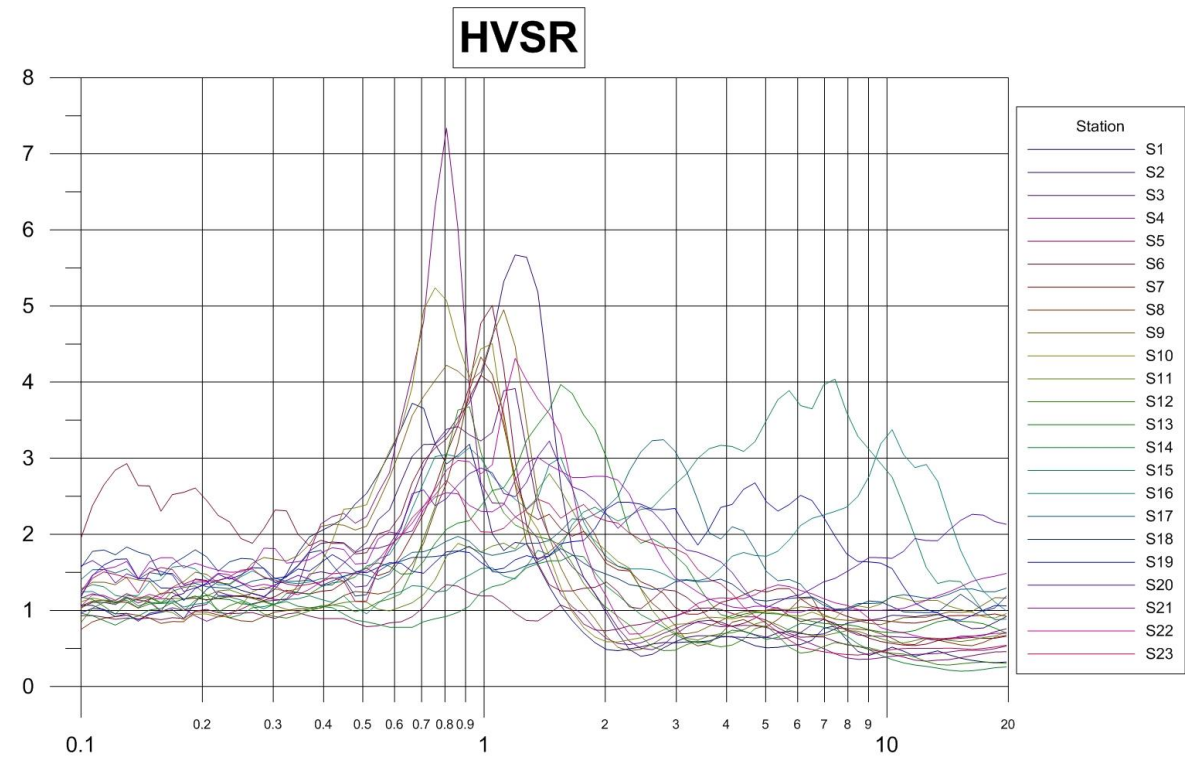

Fig. 4. HVSR average curves of the clusters in which have been considered to be dominant the structural effects of 23 measures in the area of Oliveri.

\section{NHESSD}

2, 2597-2637, 2014

Integration of HVSR measures and stratigraphic constraints

P. Di Stefano et al.

Title Page

\begin{tabular}{|c|c|}
\hline Abstract & Introduction \\
\hline Conclusions & References \\
\hline Tables & Figures \\
\hline $\mathbf{1}$ & \\
\hline & \\
\hline Back & - \\
\hline
\end{tabular}

Full Screen / Esc

Printer-friendly Version

Interactive Discussion 
Dendrogram

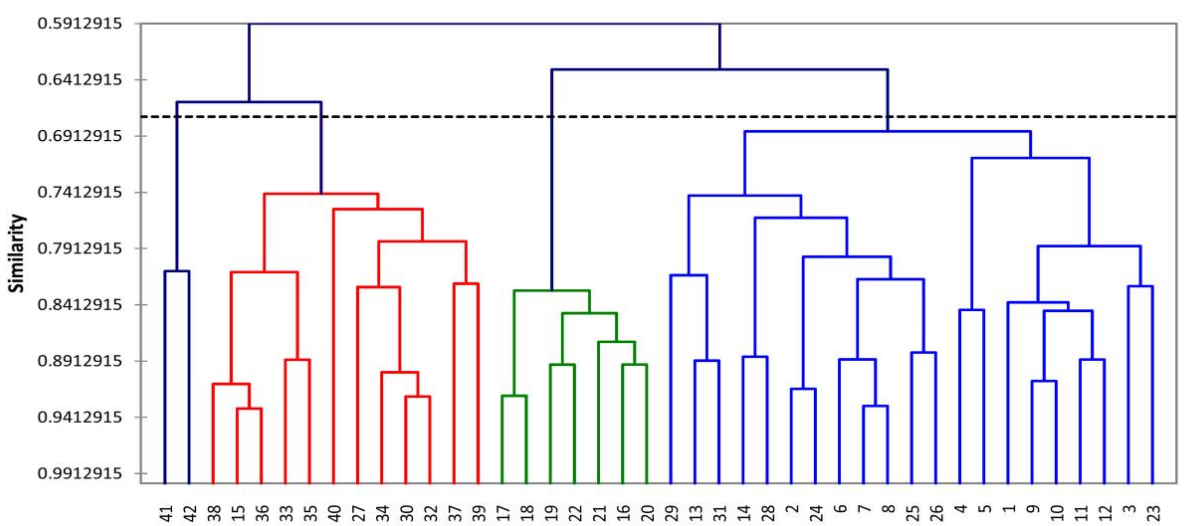

Fig. 5. Dendrogram of the clustering process.

\section{NHESSD}

2, 2597-2637, 2014

Integration of HVSR measures and stratigraphic constraints

P. Di Stefano et al.

Title Page

\begin{tabular}{c|c}
\hline Abstract & Introduction \\
\hline Conclusions & References \\
\hline Tables & Figures \\
\hline I4 & $-\mathbf{I}$ \\
\hline 4 & \\
\hline Back & Close \\
\hline
\end{tabular}

Full Screen / Esc

Printer-friendly Version

Interactive Discussion 

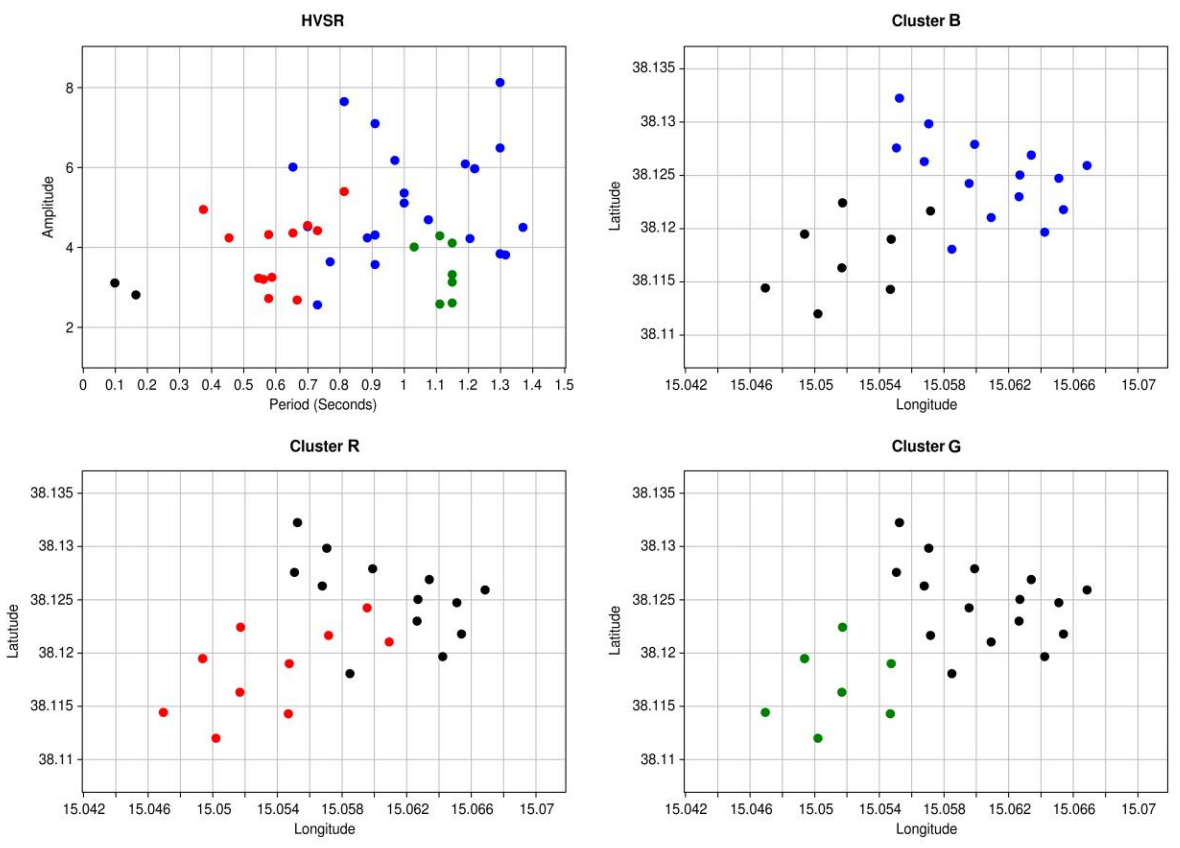

Fig. 6. Scatter plot of amplitude vs. peak frequency for the four HVSR clusters and their spatial distributions.

\section{NHESSD}

2, 2597-2637, 2014

Integration of HVSR measures and stratigraphic constraints

P. Di Stefano et al.

Title Page

\begin{tabular}{|c|c|}
\hline Abstract & Introduction \\
\hline Conclusions & References \\
\hline Tables & Figures \\
\hline I4 & \\
\hline & \\
\hline Back & Close \\
\hline Full Screen / Esc \\
\hline
\end{tabular}

Printer-friendly Version

Interactive Discussion 


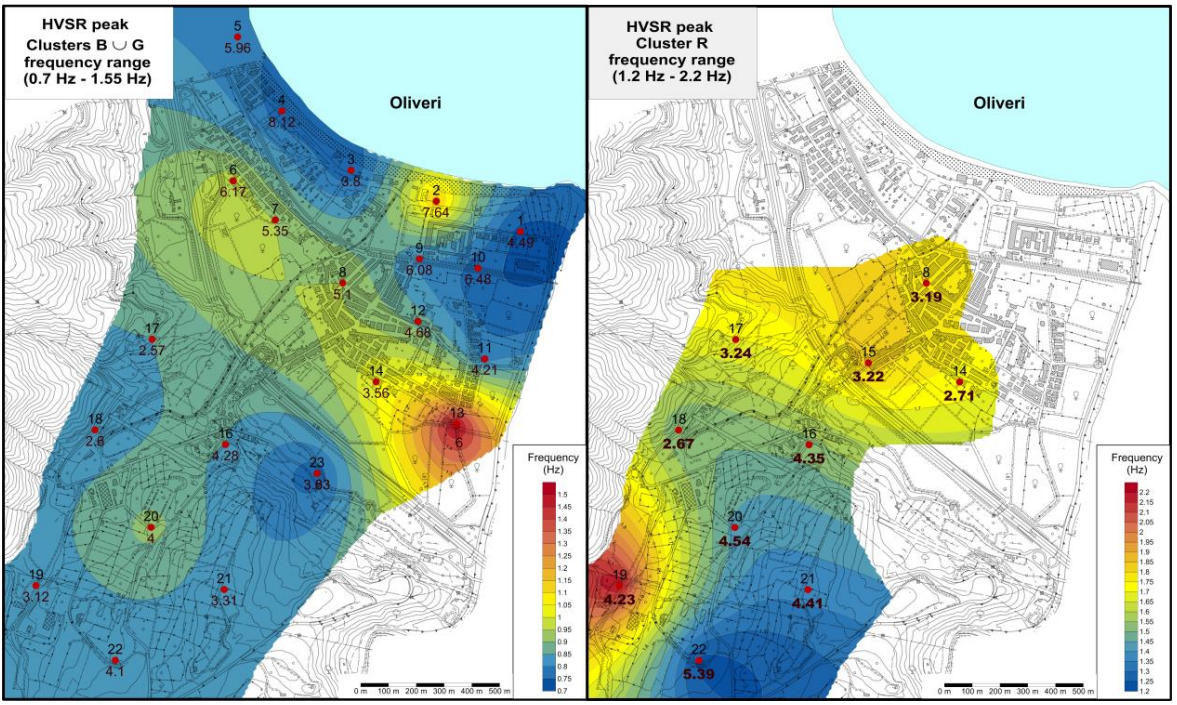

\section{NHESSD}

2, 2597-2637, 2014

Integration of HVSR measures and stratigraphic constraints

P. Di Stefano et al.

Title Page

\begin{tabular}{|c|c|}
\hline Abstract & Introduction \\
\hline Conclusions & References \\
\hline Tables & Figures \\
\hline $\mathbf{1}$ & \\
\hline & -1 \\
\hline Back & \\
\hline
\end{tabular}

Full Screen / Esc

Printer-friendly Version

Interactive Discussion 


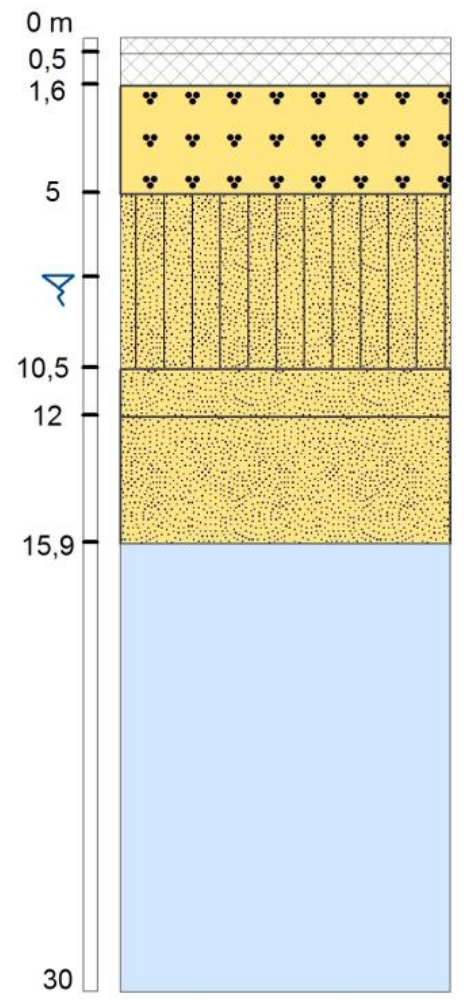

Fig. 8. Stratigraphic column of the borehole.

\section{Legend}

RI - anthropogenic deposits

$\because \quad$ SW - well-graded sands

I. SM - silty sands

. $\mathrm{SP}$ - poorly graded sands

WR - not rigid geological substate

groundwater level

\section{NHESSD}

2, 2597-2637, 2014

Integration of HVSR measures and stratigraphic constraints

P. Di Stefano et al.

Title Page

\begin{tabular}{|c|c|}
\hline Abstract & Introduction \\
\hline Conclusions & References \\
\hline Tables & Figures \\
\hline $\mathbf{I}$ & \\
\hline & \\
\hline Back & Close \\
\hline Full Screen / Esc
\end{tabular}

Printer-friendly Version

Interactive Discussion 


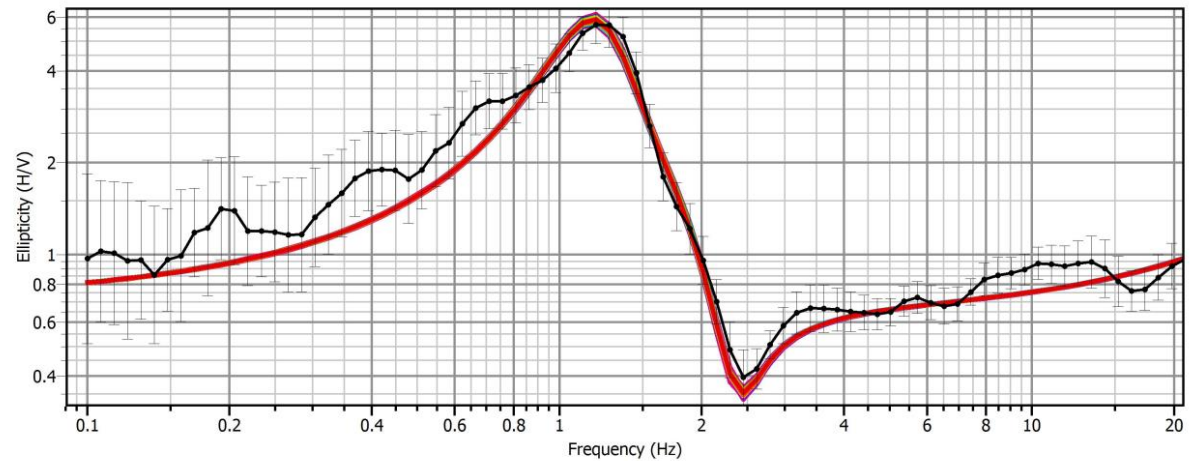

NHESSD

2, 2597-2637, 2014

Integration of HVSR measures and stratigraphic constraints

P. Di Stefano et al.
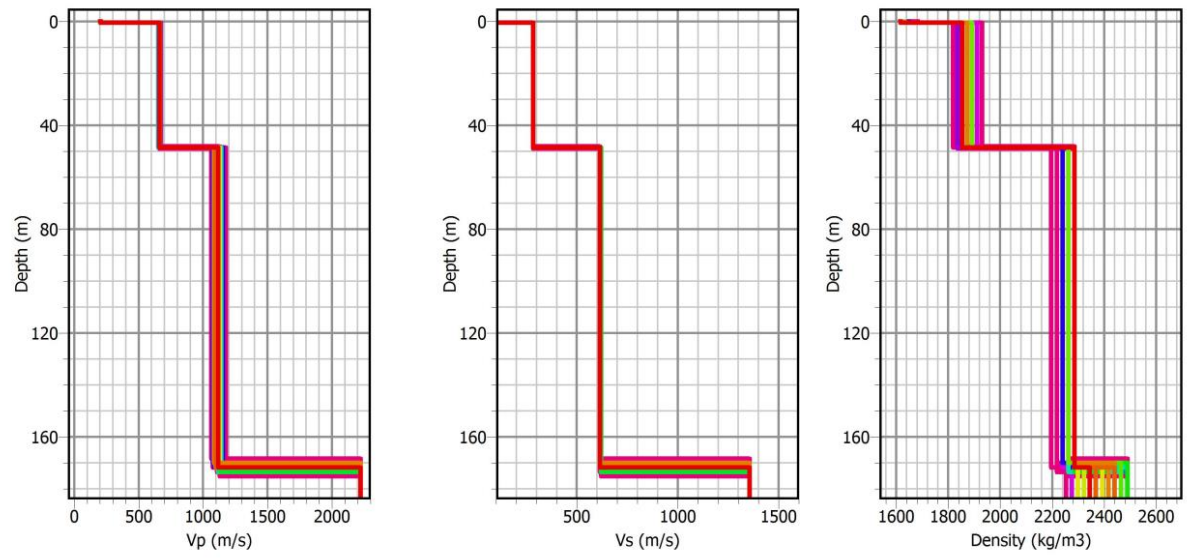

Title Page

\begin{tabular}{c|c} 
Abstract & Introduction \\
\hline Conclusions & References \\
\hline Tables & Figures \\
\hline I4 & \\
\hline Back & Close \\
\hline
\end{tabular}

Full Screen / Esc

Fig. 9. Inversion of the HVSR ellipticity curve of the measurement point n.2.

Printer-friendly Version

Interactive Discussion 


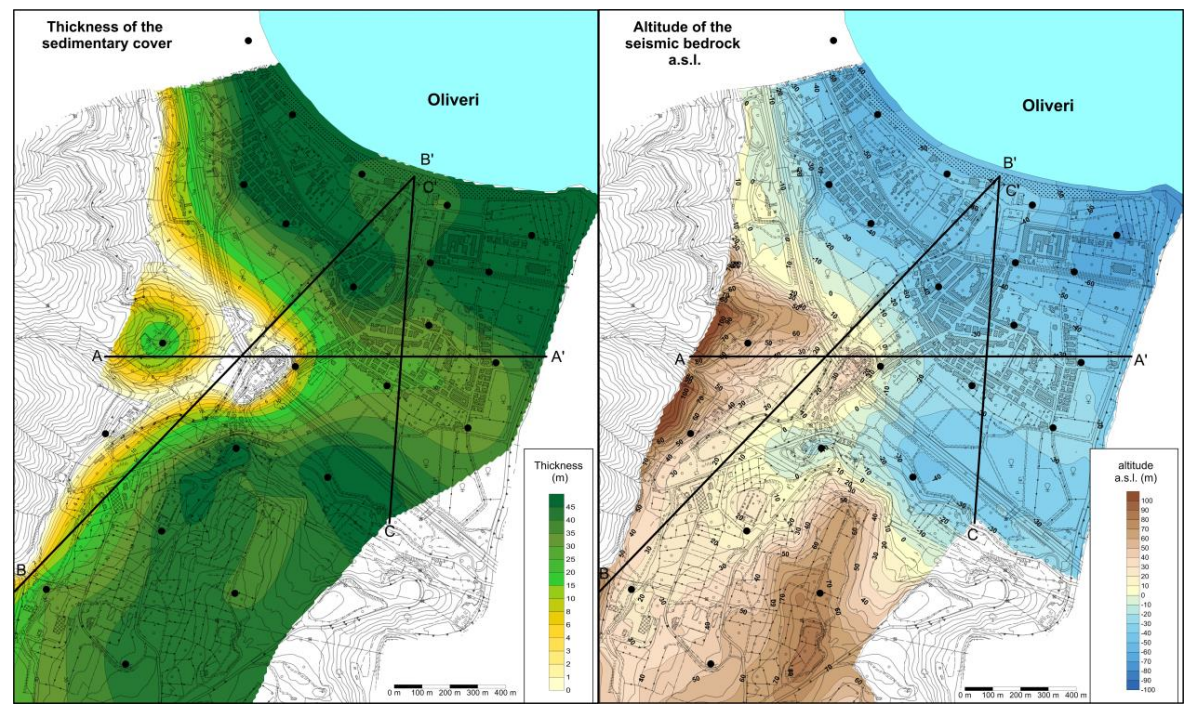

Fig. 10. Oliveri. (Left) Map of the thickness of the sedimentary cover. (Right) Map of the altitude of the seismic bedrock a.s.I.

\section{NHESSD}

2, 2597-2637, 2014

\section{Integration of HVSR measures and stratigraphic constraints}

P. Di Stefano et al.

\begin{tabular}{|c|c|}
\hline \multicolumn{2}{|c|}{ Title Page } \\
\hline Abstract & Introduction \\
\hline Conclusions & References \\
\hline Tables & Figures \\
\hline I4 & \\
\hline & \\
\hline Back & Close \\
\hline Full Screen / Esc \\
\hline Printer-friendly Version \\
\hline Interactive Discussion
\end{tabular}




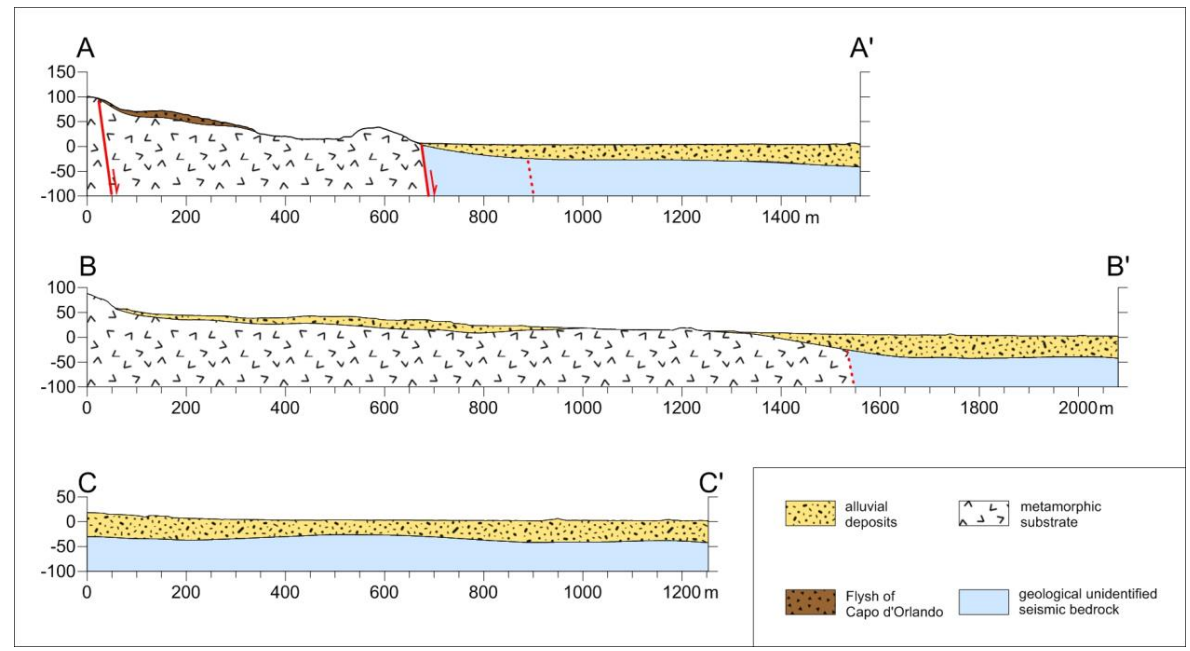

\section{NHESSD}

2, 2597-2637, 2014

Integration of HVSR measures and stratigraphic constraints

P. Di Stefano et al.

Title Page

\begin{tabular}{c|c}
\hline Abstract & Introduction \\
\hline Conclusions & References \\
\hline Tables & Figures \\
\hline $\mathbf{1}$ & \\
\hline & $-\mathbf{I}$ \\
\hline Back & \\
\hline
\end{tabular}

Full Screen / Esc

Printer-friendly Version

Interactive Discussion 